\title{
Late Pliocene rodents from the Irrawaddy sediments of central Myanmar and their palaeogeographical significance
}

\section{AUTHOR(S):}

Nishioka, Yuichiro; Takai, Masanaru; Nishimura, Takeshi; Htike, Thaung; Maung-Thein, Zin-Maung; Egi, Naoko; Tsubamoto, Takehisa; Maung, Maung

\section{CITATION:}

Nishioka, Yuichiro ... [et al]. Late Pliocene rodents from the Irrawaddy sediments of central Myanmar and their palaeogeographical significance. Journal of Systematic

Palaeontology 2014, 13(4): 287-314

\section{ISSUE DATE:}

2014-05-23

URL:

http://hdl.handle.net/2433/198843

\section{RIGHT:}

This is an Accepted Manuscript of an article published by Taylor \& Francis in Journal of Systematic Palaeontology on 23 May 2014, available online: http://www.tandfonline.com/10.1080/14772019.2014.909537.: この論文は著者最終稿です。 内容が印刷版と異なることがありますので、引用の際には出版社版をご確認ご利用ください。This is the Accepted Author Manuscript. Please cite only the published version. 


\title{
Late Pliocene rodents from the Irrawaddy sediments of central Myanmar and their palaeogeographical significance
}

\author{
Yuichiro Nishioka ${ }^{{ }^{a}}$, Masanaru Takai ${ }^{a}$, Takeshi Nishimura ${ }^{a}$, Thaung-Htike ${ }^{b}$, Zin- \\ Maung-Maung-Thein ${ }^{\mathrm{c}}$, Naoko Egi ${ }^{\mathrm{a}}$, Takehisa Tsubamoto ${ }^{\mathrm{d}, \mathrm{e}, \mathrm{f}}$ and Maung-Maung ${ }^{\mathrm{g}}$ \\ ${ }^{a}$ Primate Research Institute, Kyoto University, Inuyama, 484-8506, Japan; ${ }^{b}$ Department \\ of Geology, Shwebo University, Shwebo, Myanmar; 'Department of Geology, Mandalay \\ University, Mandalay, Myanmar; 'Hayashibara Museum of Natural Sciences, Setouchi, \\ 701-4212, Japan; ${ }^{e}$ Department of Biosphere-Geosphere Science, Okayama University of \\ Science, Okayama, 700-0005, Japan; ${ }^{f}$ Department of Earth Sciences, Faculty of \\ Science, Ehime University, Matsuyama, 790-8577, Japan; ${ }^{g}$ Department of Geology,
}

Magway University, Magway, Myanmar

*Corresponding author. Email: nishioka.yuichirou.8s@ kyoto-u.ac.jp

The Upper Pliocene Irrawaddy sediments in the Gwebin area of central Myanmar recently yielded a rodent assemblage that contains nine species belonging to four families: four species of Muridae, three of Hystricidae, one of Spalacidae, and one of Sciuridae. The murids consist of Hapalomys cf. longicaudatus, Maxomys pliosurifer sp. nov., Rattus jaegeri and cf. Rattus sp. indet., which include both extinct and extant forms. Maxomys pliosurifer is relatively similar to Maxomys surifer that lives in SouthEast Asia in terms of tooth morphology but retains plesiomorphic features shared with the ancestral rat, Karnimata, and possible sister genera of Maxomys, such as Ratchaburimys and Millardia. The three hystricids belong to the genus Hystrix and consist of two extinct brachydont species (Hystrix paukensis and Hystrix sp. indet.) and one hypsodont species similar to living form (Hystrix cf. brachyura). This finding indicates that primitive brachydont species and derived hypsodont species of Hystrix had likely coexisted in the locality, but the brachydont species are significantly more 
common amongst specimens collected from the Gwebin area. The spalacid species is Cannomys cf. badius and the sciurid species is Menetes sp. indet. These two rodents are similar to living species in continental South-East Asia although they show minor differences in tooth characteristics compared to the living forms. Some species and genera of the fossil rodent assemblage from the Gwebin area also occur in Upper

Pliocene localities of Thailand, suggesting chronological correlation between these two faunas. Moreover, these fossil rodent assemblages are composed primarily of the species distributed endemically in continental South-East Asia. Late Pliocene rodents of continental South-East Asia were affectedby river barriers that formed during the Mio-Pliocene, and they were probably not able to disperse from SouthEast Asia into South and East Asia.

Keywords: Rodentia; Pliocene; Irrawaddy sediments; biogeography; Myanmar; South-East Asia

\section{Introduction}

Rodents (Mammalia) are one of the most diverse orders in South-East Asia, and their distribution is affected stronglyby geographical barriers such as seas, high mountains and rivers. The zoogeographical region of continental South-East Asia is included in the Indochinese Division that is a part of the Indomalayan Region, or Oriental Region (Corbet \& Hill 1992). The Indochinese Division is boundedby the Himalaya-Tibetan Plateau in the north, the Brahmaputra and Ganges Rivers in the west, the Kra Isthmus in the Malay Peninsula in the south, and the mountain ranges or rivers of southern China in the north-east. Due to thesephysical barriers, there are many endemic genera and species of mammals living in South-East Asia mainland. Therodents Maxomys surifer and Hystrix brachyura are two examples (Corbet \& Hill 1992). 
There are eight main rivers in continental South-East Asia: the Brahmaputra, Irrawaddy (or Ayeyarwady), Salween, Chao Phraya, Mekong, Red, Pearl and Yangtze Rivers. The past flow and channel shifts of these rivers are important factors that have controlled the distributional patterns of some mammals (Meijaard \& Groves 2006). The main rivers started flowing in the Late Eocene and changed their courses in the Oligocene due to the elevation of the Himalaya-Tibetan Plateau and its branches, such as the Indo-Burma Ranges (e.g. Clark et al. 2004; Clift et al. 2006, 2008).

Rodent fossils of the Late Miocene to Early Pleistocene from South Asia and East Asia are well known. Some families of rodents are likely to have originated in the Miocene of South Asia and dispersed westward and eastward, as the oldest fossils of the Muridae, Spalacidae and Hystricidae were discovered in the Lower or Middle Miocene of Indo-Pakistan. The primitive group of Asian rodents is represented by the rodent assemblage from the Upper Miocene of the Siwalik Group and includes the murids Karnimata, Progonomys and Parapodemus, the spalacids Kanisamys, Rhizomyides and Brachyrhizomys, and the hystricids Hystrix sivalensis (also referred to as H. primigenia) (Lydekker 1878; Jacobs 1978; Flynn 1982; Patnaik 2003). Since the Pliocene, these primitive species have been replaced by extant forms living in South Asia, such as the murids Golunda, Millardia, Dilatomys, Cremnomys, Mus and Bandicota, the spalacid Rhizomys, and the hystricid Hystrix leucurus (or H. indica) (Patnaik 2003; Patnaik \& Nanda 2010).

The rodent assemblage from the Upper Miocene of East Asia is represented by Sciuridae and Castoridae. These taxa have not been found in contemporaneous deposits of South Asia. On the other hand, the Upper Miocene of China shares primitive forms of hystricid rodents with those of Indo-Pakistan. Hystrix lufengensis and $H$. gansuensis from the Yunnan and Gansu areas in China are moderately large and have low-crowned cheek teeth relative to extant species of Hystrix (Wang \& Qiu 2002; Wang \& Qi 2005). These features resemble $H$. sivalensis and H. primigenia from the Middle Siwaliks and the Upper Miocene of Europe (Weers \& Rook 2003). 
Although rodent fossils from the Pliocene of East Asia are fragmentary, they are composed mainly of species belonging to the extant genera distributed in South-East Asia or China, such as Leopoldamys and Apodemus (Zheng 1993; Jin et al. 1999). Fossil records and the distributions of extant species indicate that these genera have diversified at species level since the Early Pleistocene in southern and northern China (Corbet \& Hill 1992; Zheng 1993; Jin et al. 2009).

There are fewer late Neogene rodent fossils in continental South-East Asia than there are in South Asia and East Asia, but a continuous fossil record of rodents has been reported from the Upper Pliocene to Holocene of Thailand (e.g. Ginsburg et al. 1982; Chaimanee et al. 1993, 1996; Chaimanee 1998). Rodent fossil assemblages in Thailand are roughly divided into two faunas: one is from the Upper Pliocene to Lower Pleistocene, and the other from the Middle Pleistocene to Holocene (Chaimanee 1998). The former includes extinct genera and species of murids, such as Ratchaburimys, Prohadromys and Saidomys, mixed with extant genera and some of the rodent fauna from the Upper Pliocene to Lower Pleistocene of East Asia. Moreover, the Upper Pliocene of Thailand is also characterized by the occurrence of the ancestral species of the Rattus sensu lato group, including Rattus and Maxomys, which diversified in the Indochinese Division during the Pliocene and Pleistocene.

Although mediumto large-sized mammal fossils are very common in the Irrawaddy sediments, rodent fossils have only recently been discovered in these sediments (Colbert 1938; Nishioka et al. 2011; Zin-Maung-MaungThein et al. 2011). The discovery of rodent fossils in the Plio-Pleistocene of central Myanmar fills the geographical gap between South Asia and East Asia and the chronological gap during the Pliocene. Moreover, the Plio-Pleistocene age corresponds to the time of diversification of extant species of rats in continental South-East Asia, as determined from the fossil record and biomolecular studies (Verneau et al. 1997; Chaimanee \& Jaeger 2001). Here, we systematically describe the Plio-Pleistocene rodent assemblage of central Myanmar by reviewing its fossil-bearing age and 
focusing on the relationship between the speciation of living rodents in the Indochinese Division and geographical changes that occurred during the Pliocene in South-East Asia.

\section{Geological setting}

The Irrawaddy sediments are widely distributed along the Irrawaddy and Chindwin rivers in central Myanmar and yield the remains of terrestrial and aquatic vertebrate fossils. These sediments consist mainly of fluvial deposits and their thickness has been estimated to be 2000-3000 m (Bender 1983). The base of the sediments unconformably overlies the Pegu Group, which consists of shallow marine/freshwater deposits of Oligocene to Miocene age (Stamp 1922). The uppermost part of the Irrawaddy sediments is covered by middle to late Pleistocene river terrace deposits.

The Irrawaddy sediments have been traditionally subdivided into lower and upper parts based on palaeontological and lithological criteria (Stamp 1922; Colbert 1938; Bender 1983). Their ages have been estimated by correlation with the Siwalik Group of Indo-Pakistan. The Lower Irrawaddy sediments correlate to the Dhok Pathan Formation in the Middle Siwaliks, and possibly to the uppermost part of the Chinji Formation in the Lower Siwaliks, suggesting that the Lower Irrawaddy fauna dates between the latest Middle Miocene and Early Pliocene (Colbert 1938; Chavasseau et al. 2006; Takai et al. 2006; Zin-MaungMaung-Thein et al. 2011). The Upper Irrawaddy sediments correlate to the Upper Siwaliks, which date from the Upper Pliocene to the Lower Pleistocene (Colbert 1938; Bender 1983; Zin-Maung-MaungThein et al. 2008).

The fossils used in this study were collected in the Gwebin area, including Gwebin and Than-bin-gyaung villages, Seikpyu Township (Fig. 1). The Irrawaddy sediments in the Gwebin area are distributed along the eastern flank of the Salin syncline, the axis of which runs at 94³0'E near Seikpyu Township. These sediments are composed mainly of alternating brown, massive siltstone and thin-bedded, fine- 
grained sandstone (Fig. 2). The sandstone beds sometimes show sedimentary structures, such as planar and trough cross-bedding, sandstone concretions and caliche. Both siltstone and sandstone beds usually yield many reptile remains, including those of crocodiles (e.g. ?Gavialis sp.) and turtles (e.g. Chitra sp.) (Moe Nyunt 1987; T. Sonoda, pers. comm.).

There are 15 fossil localities in the Gwebin area, and rodent fossils have been collected at five of them: Mg1/2, Gbn5, GbnF1, TBG1 and Psw1 (Fig. 1; Table 1). $\mathrm{Mg} 1 / 2$ is a small area in which we discovered many fossils of small mammals, including rodents and primates. Sediments at this site are formed primarily of alternations of siltstone and sandstone beds with cross bedding. The top of the sediments is covered discontinuously by river terrace deposits containing rounded pebbles. Gbn5 and GbnF1 are small sites near Mg1/2. Rodent fossils collected at these localities are recovered from almost the same horizon as at $\mathrm{Mg} 1 / 2$.

TBG1 is located near Than-bin-gyaung village. The sediments at TBG1 include a $20 \mathrm{~cm}$ thick conglomerate with black sandy concretion that is absent at the other localities in the Gwebin area. Rodent fossils at TBG1 were discovered in a pale brown siltstone bed lying under a thin sandstone bed (Fig. 2). Psw1 is situated in the north-western highland area (Fig. 1). The sediments at this locality are slightly younger than the fossil-bearing horizon of $\mathrm{Mg} 1 / 2$ because the bedding plane is almost horizontal or is inclined slightly to the west. The upper part of the sediments at Psw1 includes a conglomerate layer, but the layer is not correlated with the black conglomerates at TBG1. Lithological and palaeontological observation indicate that fossil-bearing horizon at Psw1 is undoubtedly included in the Upper Irrawaddy sediments.

A total of 470 mammal specimens have been discovered to date, including seven orders, 16 families, 22 genera and 27 species (Table 2). The geological age of the Gwebin fauna has been preliminarily documented by comparing the biostratigraphical ranges of these mammalswith those from other localities (MoeNyunt 1987; Thaung-Htike et al. 2006; Zin-Maung-Maung-Thein et al. 2008; Egi et 
al. 2011; Tsubamoto et al. 2012). The Gwebin fauna is characterized by the existence of Sus, which is a Plio-Pleistocene indicator; the absence of Sivachoerus, Propotamochoerus and Dorcatherium, which are Mio-Pliocene indicators; and taxa shared with Indo-Pakistan and China faunas (Colbert 1935; Lucas 2001; Barry et al. 2002; Badgley et al. 2008). Sivachoerus is regarded to have migrated to South and South-East Asia in the latest Miocene and disappeared by the Late Pliocene (Pickford 1988). The absence of this genus therefore suggests that the fauna is stratigraphically younger than the Early Pliocene. Propotamochoerus also disappeared in the Early Pliocene of Asia, replaced by Sus in the Late Pliocene.

Amongst Tragulidae (Artiodactyla), both Dorcatherium and Dorcabune have been reported from the Upper Miocene to Lower Pliocene of central Myanmar, but Dorcatherium likely disappeared in Eurasia around 5 Ma (Lucas 2001; R€ossner 2007; Zin-Maung-Maung-Thein et al. 2011). The co-occurrence of the hippopotamid Hexaprotodon sivalensis and the anthracotheriid Merycopotamus dissimilis was between 4 and $3 \mathrm{Ma}$ in the Siwalik fauna, indicating the Late Pliocene age (Barry et al. 2002; Badgley et al. 2008; Patnaik 2013). Therefore, the Gwebin fauna is surely younger than the Lower Irrawaddy horizon (Middle Miocene to Early Pliocene), and is probably Late Pliocene.

\section{Material and methods}

A total of 61 rodent specimens were examined in this study (Supplemental Appendix 1). The fossils were obtained by surface collection and screen-wash methods.

Irrawaddy sediments for screen-wash were collected from the basal part at the $\mathrm{Mg} 1 / 2$ locality (Fig. 2). The collected sediments were first washed and screened using 0.5-1 $\mathrm{mm}$ meshes. After drying the sediment residues, bones and teeth were picked visually.

Specimens collected by the Myanmar-Japan Palaeontological Expedition Team were catalogued as NMMP-KUIR specimens and stored in the Southern Branch, 
Department of Archaeology, National Museum and Library, Ministry of Culture (Yangon). The specimens indicated by NMMP-M1 were stored in the National Museum (Yangon) by the Myanmar Expedition Team No. 1. These catalogue indices are hereafter abbreviated as 'IR' and 'M1-', respectively.

Measuring methods and terminology for rodent teeth follow Miller (1912), Wang \& Qi (2005), Flynn (1982) and Kawamura (1988) for murids, spalacids, hystricids and sciurids, respectively (Fig. 3). Teeth of the spalacids andhystricids were measured using a digital calliper, NTD12P15C (Mitutoyo Corp., Japan), and those of the murids and the sciurids were measured using an XY stage digital calliper, TD100 (Shodensha, Inc., Japan) with a stereomicroscope, L-50 (Hozan Tool Ind. Co., Japan). For comparative materials, we used specimens of rodents stored in the Bombay Natural History Society (Mumbai), the Kyoto University Museum (Kyoto), the Primate Research Institute, Kyoto University (Aichi), and the Senckenberg Forschungsinstitut und Naturmuseum (Frankfurt).

\section{Institutional and locality abbreviations}

AML-N-IR: Department of Archaeology, National Museum and Library - Northern Branch, Irrawaddy, Myanmar; AMNH: American Museum of Natural History, New York, USA; Gbn: Gwebin, Myanmar; Mg: Maung-Maung’s site, Myanmar; NMMPKU-IR: National Museum of Myanmar, Palaeontology, Kyoto University, Irrawaddy, Myanmar; Psw: Peikswe, Myanmar; SMF/PA: Senckenberg Forschungsinstitut und Naturmuseum, Frankfurt/Palaeontology, Germany; TBG:Than-bin-gyaung, Myanmar.

\section{Systematic palaeontology}

Order Rodentia Bowdich, 1821 
Family Muridae Illiger, 1811

Genus Hapalomys Blyth, 1859

Type species. Hapalomys longicaudatus Blyth, 1859.

Hapalomys cf. longicaudatus Blyth, 1859

(Figs 4, 5A, 6A)

1859 Hapalomys longicaudatus Blyth: 296.

Material. A right $M^{1}$ (IR 2543); a left maxilla with $M^{1}$ (IR 1966); two left $M^{1}$ (IR 2541, IR 2542); a right mandible with $\mathrm{I}_{1}$ and $\mathrm{M}_{1}-\mathrm{M}_{3}$ (IR 1955); a right mandible with $\mathrm{M}_{1}$ (IR 2524); two right $\mathrm{M}_{2}$ (IR 2105, IR 2545); a left mandible with $\mathrm{M}_{2}-\mathrm{M}_{3}$ (IR 1965); two left mandibles with $\mathrm{M}_{2}$ (IR 1967, IR 2523); a left $\mathrm{M}_{2}$ (IR 2544).

Locality. $\operatorname{Mg} 1 / 2$.

Measurements. See Supplemental Appendix 2.

Description. The outline of $\mathrm{M}^{1}$ is rounded and rectangular in the occlusal view. The crown is comprised of three transverse rows, including three cusps on each row. The anterior synclines are strongly deep. Two of the specimens (IR 2542 and IR 2543) have an anterior cingular cusplet ( $\mathrm{t} 1$ bis) on the anterior synclines, while IR 1966 lacks it. The first row, composed of cusps t 1 to $t 3$, is symmetrically disposed. Cusp t 1 is almost as large as cusp t3. Cusp t 2 has a triangular shape in occlusal view and does not connect with either cusp $\mathrm{t} 1$ or $\mathrm{t} 3$ at an early stage of wear. Cusp $\mathrm{t} 3$ of IR 2543 develops a tiny posterior spur on its posterolingual corner. The second row is composed of cusps t 4 to t6 and has a similar occlusal pattern to that of the first row, but the former is comparatively large. Each cusp on the second row is isolated due to 
the presence of deep valleys between the rows. Cusp t6 is placed more distally than cusp t4. Cusps t5 and t6 sometimes have a posterior spur, similar to the feature on cusp $\mathrm{t} 3$ of IR 2543. The third row composed of cusps t7 to $\mathrm{t} 9$ is separated from the second row by a deep valley. Cusp $\mathrm{t} 7$ is slightly smaller than cusp $\mathrm{t} 9$. The posterior interfacet on the third row runs obliquely in occlusal view because cusp t 9 is placed distally like cusp t6. Cusp t8 is the largest of all cusps on the third row and connected to cusps $\mathrm{t} 7$ and $\mathrm{t} 9$ at their posterior corners. There is no cingulum on the posterior wall of cusp t8. Three main roots and two small roots are present on the labial side and the lingual side, respectively.

Only the anterior parts, not the processes, of the mandibles are preserved (IR 1955, IR 1967, IR 2523 and IR 2524). The diastema is anteroposteriorly short, crossing at right angles the anterior wall of the alveolar bone. The mental foramen opens somewhat anterior to the anterior root of $\mathrm{M}_{1}$. The upper masseteric crest is present, but is weaker than the lower one. The anterior ends of the crests cross below the anterior root of $\mathrm{M}_{1}$. The posterior end of the symphyseal eminence is situated below the interface between $\mathrm{M}_{1}$ and $\mathrm{M}_{2}$. The mandibular depth at the $\mathrm{M}_{1}$ position is slightly deeper than that at $\mathrm{M}_{3}$.

$\mathrm{M}_{1}$ is rectangular in occlusal view. The crown comprises three transverse chevrons with strong labial cusplets. Although all $\mathrm{M}_{1}$ specimens lack their anterior parts, there may be a small anterocentral cusp on the first chevron of IR 1955. The anterolabial cusp and the anterolingual cusp are separated by a shallow gap. The protoconid on the second chevron is almost as large as the metaconid on the other side. There is a small anterior labial cusplet immediately adjacent to the protoconid. The third chevron is comparatively wide and includes the hypoconid and entoconid. The hypoconid and entoconid are connected at their mesial corners, resulting in a pointed chevron in occlusal view. The occlusal shape of each cusp on the second and third chevrons is an inverted equilateral triangle. The posterior labial cusplet is extremely large and isolated from the hypoconid. There is a small posterior cingulum that has a triangle outline. The alveolus of $\mathrm{M}_{1}$ has five root sockets for large anterior and 
posterior roots, a small lingual root, and two labial roots.

$\mathrm{M}_{2}$ is square in occlusal view. The enamel pattern is similar to that of the second and third chevrons of $\mathrm{M}_{1}$. The anterolabial cusp is well developed and elongated anteroposteriorly at a moderate wear stage. The first chevron is composed of the protoconid and the metaconid. The metaconid is separated from the anterolabial cusp. The protoconid is as large as the metaconid. The posterior labial cusplet is always present and is isolated from the second chevron. This cusplet is larger than the anterior labial cusplet in IR 1955, IR 1965, IR 1967 and IR 2523, but is smaller than the anterior labial cusplet in the other M2 specimens. There is a small triangle-shaped posterior cingulum behind the medial valley between the hypoconid and the entoconid on the third chevron. The alveolus of $\mathrm{M}_{2}$ has two root sockets that elongate labiolingually.

$\mathrm{M}_{3}$ has an inverse trapezoidal shape in occlusal view. It has a small anterolabial cusp that is like a cingulum but does not have a labial cusplet. A punctiform posterior cingulum is present. There are two roots on the anterior and posterior sides.

Remarks. Hapalomys molars are unique in that they have rounded triangular cusps that are nearly equal in size, deep valleys between them, and a strong cusp $\mathrm{t} 7$ in the upper molars (Musser 1972). The genus is an arboreal marmoset rat that is distributed in southern continental South-East Asia, and includes two extant $(H$. longicaudatus and $H$. delacouri) and four extinct (H. eurycidens, H. angustidens, $H$. gracilis and $H$. khaorupchangi) species from Thailand and China. The specimens in the present study are similar to H. longicaudatus in that they are the largest of all the examined species. However, there are some differences between the fossils and the living form. The occlusal outline of $\mathrm{M}^{1}$ from Gwebin is slightly wider than that of living specimens, and the anterior wall of the former expands anteriorly. The occlusal surface of each cusp of the fossil specimens is shorter, anteroposteriorly, than those of the extant species. Moreover, the extant specimens usually have two 
anterior cusplets ( $\mathrm{t} 1$ bis and $\mathrm{t} 2$ bis) on $\mathrm{M}^{1}$, while this character varies between the three fossil specimens. At least, the fossil form does not have the $\mathrm{t} 2 \mathrm{bis}$. The Gwebin fossil specimens have much larger crowns than living H. longicaudatus (Musser 1972; Chaimanee 1998; see also Fig. 7). However, the specimens in the present study were classified as $H$. cf. longicaudatus and the observed differences were attributed to intraspecific variations because there were insufficient materials to distinguish the two forms specifically.

Another extant species, Hapalomys delacouri, is a small-sized species that existed from the Middle Pleistocene to the Holocene in South-East Asia and southern China (Zheng 1993; Chaimanee 1998). H. delacouri is similar to H. cf. longicaudatus from the Gwebin area in that it lacks additional anterior cusplets on anterior synclines. However, H. delacouri usually has a posterior cingulum with cusp t8. H. eurycidens, $H$. angustidens and $H$. gracilisis are Early Pleistocene (or latest Pliocene) species from southern China and differ from H. longicaudatus in that they have relatively smallsized teeth and a posterior cingulum with cusp $t 8$ on $\mathrm{M}^{1}$ (Zheng 1993). $H$.

khaorupchangi is another extinct species that was recorded from the Lower to Middle Pleistocene of Thailand (Chaimanee 1998). This species is intermediate between $H$. longicaudatus and $H$. delacouri in molar sizes (Fig. 7). The molar patterns of $H$. khaorupchangi are close primarily to those of $H$. longicaudatus, although the former is distinguished by the following diagnostic character of M1: a relatively narrow crown, well-defined anterocentral cusp, and weak labial cusplets that are like a cingulum.

Stratigraphical and geographical distributions. UpperPliocene to Holocene of Myanmar, Thailand and Peninsular Malaysia.

Genus Maxomys Sody, 1936

Type species. Maxomys bartelsii Jentink, 1910. 


\section{Maxomys pliosurifer sp.nov.}

(Figs 5B, 6B, 8A-G)

Material. Holotype: a right maxilla with $\mathrm{M}^{1}-\mathrm{M}^{3}$ (IR 1995). Paratypes: a left $\mathrm{M}^{1}$ (IR 2552); a right $\mathrm{M}^{2}$ (IR 2553); a left $\mathrm{M}^{2}$ (IR 2554); a left mandible with $\mathrm{M}_{1}-\mathrm{M}_{3}$ (IR 2067); a right mandible with $M_{1}$ (IR 2057); a left $M_{1}$ (IR 2556).

Type locality. $\operatorname{Mg} 1 / 2$.

Etymology. Plio is named after the Pliocene and-surifer after Maxomys surifer, an extant species that commonly lives in South-East Asia.

Diagnosis. Medium-sized species of Maxomys with a tiny slender cusp t9 on $\mathrm{M}^{1}$ and $\mathrm{M}^{2}$, four roots on $\mathrm{M}^{1}$, labiolingually elongated cusp $\mathrm{t} 1$ on $\mathrm{M}^{2}$ and $\mathrm{M}^{3}$, distinct cusp $\mathrm{t} 3$ on $\mathrm{M}^{2}$, distinct anterocentral cusp on $\mathrm{M}_{1}$, and a large anterolabial cusp on $\mathrm{M}_{2}$ and $\mathrm{M}_{3}$.

Measurements. See Supplemental Appendix 2.

Description. The holotype, IR 1995, is a right maxilla with three complete, moderately worn, molars. The measurements and cusp patterns of this maxilla fit well with those of IR 2067, a left mandible with molars, which indicates that the specimens derived from the same species. The crowns of the molars are not as high as those of Rattus, the common rat. The maxillary bone is fragmentary, but the alveoli, posterior end of the incisive foramen, and a partial zygomatic plate are preserved. There is no masseteric knob under the zygomatic plate. The end of the incisive foramen approaches as far as the anterior root of $\mathrm{M}^{1}$.

M $^{1}$ of IR 1995 lacks its outside enamel on the labial side, but it has a nearly oval 
outline in occlusal view. The crown is comprised of three transverse rows forming a chevron shape, which is representative of a typical murid with stephanodont molars. There is a weak precingulum between the anterior synclines on the anterior wall. The first row is composed of cusps $t 1$ to $t 3$, and cusp $t 3$ is much reduced. Cusp $t 1$ is as large as cusp $\mathrm{t} 2$ and is situated more posteriorly than cusps $\mathrm{t} 2$ and $\mathrm{t} 3$. Cusp t6 is connected with cusp 44 on the second row by wearing. The second row is composed of cusps 44 to $t 6$ and is similar in shape to the first row. Cusp t6 is smaller than the other cusps on the second row, but is larger than cusp $\mathrm{t} 3$. The second row connects with the third row on the labial and lingual cusps in IR 1995. The third row is composed of cusps $t 8$ and $t 9$, with cusp $t 7$ missing. Cusp t8 is elliptical and connected with cusp t9 on the anterolabial side. Cusp t9 is very small and slender and is situated between cusps t6 and t8. Cusp t9 would easily connect with the cusp t6 at an early wear stage. Cusp t8 of IR 2553 has a vestigial spur on the lingual side. The posterior cingulum is always absent. The radical face is anchored by four roots: a large anterior root, two lingual roots, and a posterior root. In lateral view, all cusps are sharply pointed at the wear stage of the examined specimens.

$\mathrm{M}^{2}$ has a rounded square-shape in occlusal view. The crown is comprised of two isolated cusps (t1 and $\mathrm{t} 3$ ) and two chevron-shaped rows. Cusp t1 is large, extending to cusps $\mathrm{t} 3$ and $\mathrm{t} 4$. Cusp $\mathrm{t} 3$ is small and distinctly forms a triangle. Cusp t3 of IR 2554 is elongated labiolingually. The transverse rows on $\mathrm{M}^{2}$ are similar to the second and third rows on $\mathrm{M}^{1}$. Cusp $\mathrm{t} 4$ is elongated posteriorly, like a posterior spur. Cusp t6 approaches cusp t9, and they are connected by wearing. Neither cusp $\mathrm{t} 7$ nor a cingulum is present between cusps $\mathrm{t} 4$ and $\mathrm{t} 8$. At least two roots are observed.

$\mathrm{M}^{3}$ has a rounded triangular shape in occlusal view. The crown comprises isolated cusp t1, a row composed of cusps $t 4$ to t6, and an isolated cusp t8. Cusp t1 is very large, and is similar to that on $\mathrm{M}^{2}$. Cusp $\mathrm{t} 3$ is absent. The middle row is asymmetrical because of cusp t6 is much reduced. The labial side of cusp t8 is connected to cusp t6. At the wearing stage of IR 1995, cusp t8 is also connected to 
cusp $t 4$ by a slender bridge. There is a valley between cusps $t 4$ and $t 8$ on the lingual side. There are two or three roots.

A mandibular specimen, IR 2067, is mostly broken, and its surface is covered by sedimentary matrix (Fig. 6B). The mandibular body is comparatively deep and robust. The diastema crosses the anterior wall of the alveolar bone at right angles. This anterior wall is as deep as the diastema directly below it. The mandibular body under $\mathrm{M}_{1}$ is slightly deeper than that under $\mathrm{M}_{3}$. The masseteric crests do not look prominent as a result of weathering. The lower molar row curves weakly inwards in occlusal view.

$\mathrm{M}_{1}$ has a slender rectangular shape in occlusal outline, and the anterior part is almost as wide as the posterior width. The occlusal enamel pattern comprises three chevron-formed laminae and a posterior cingulum. The first chevron is composed of two same-sized cusps, an anterolabial cusp and an anterolingual cusp. The anterocentral cusp is always present on the anterior side between the anterolabial cusp and the anterolingual cusp. The first chevron connects with the second chevron in the centre by wearing, creating an X-pattern. The second chevron is composed of the protoconid and the metaconid. The protoconid is slightly larger than the metaconid. The third chevron is composed of the hypoconid and the entoconid and has a similar pattern to that of the second chevron. A relatively large accessory cusp (posterior labial cusplet) is present beside the hypoconid, but there is no anterior labial cusplet. The occlusal outline of the posterior cingulum has a rounded diamond shape and is elongated labiolingually.

$\mathrm{M}_{2}$ is square in occlusal view. The crown comprises two chevron-formed laminae and a posterior cingulum. The first and second chevrons have patterns similar to that of the middle lamina in $\mathbf{M}_{1}$. Both the anterolabial cusp and posterior labial cusplet are well developed on the labial side. The anterolabial cusp is extended labiolingually and connected to the anterolingual wall of the protoconid. The first chevron is slightly wider than the second chevron. The posterior cingulum is slender and transversely elongated. 
$\mathbf{M}_{3}$ has two simple laminae and a rounded inverse triangular shape in occlusal view. The protoconid on the labial side of the first lamina is larger than the metaconid on the other side. The anterolabial cusp is situated over the protoconid on the occlusal surface. The second lamina is composed primarily of the entoconid and forms a semicircular shape. The entoconid is connected with a tiny cusplet on the labial side, probably corresponding to a hypoconid or posterior labial cusplet.

Remarks. The examined specimens share the following features of upper molars with extant Maxomys species: (1) medium size; (2) no cingulum or cusp at the position of cusp t7; (3) cusps t1 and t4 approaching posteriorly; (4) much reduced cusp t9; (5) no posterior cingulum; (6) $\mathrm{M}^{1}$ with reduced cusp $\mathrm{t} 3$ and three or four roots; (7) $\mathrm{M}^{2}$ with well-developed cusp $\mathrm{t} 1$ and small cusp $\mathrm{t} 3$; and (8) $\mathrm{M}^{3}$ without cusp $\mathrm{t} 3$. The combination of these characteristics distinguishes Maxomys from other genera, such as the Rattus sensu lato group in South Asia and South-East Asia (e.g. Leopoldamys, Niviventer, Berylmys, Bandicota, Rattus, Golunda, Cremnomys and Hadromys).

Some of the dental features of Maxomys are shared with Millardia, which is distributed in South Asia and central Myanmar. The obvious differences between the two genera are the degree of cuspidation and the position of cusp t9 in the upper molars. Millardia has more cuspidated molars than Maxomys, as it has deep valleys between cusps. Moreover, cusp $\mathrm{t} 9$ of Millardia is elongated more transversely than that of Maxomys, and the former is sometimes connected to cusp t6 by a stephanodont crest. However, cusp t9 of the examined specimens is connected by its anterolabial extension, as in a cingulum. In terms of the lower molars, Millardia usually has a relatively simple enamel pattern without any accessory cusps including an anterocentral cusp on $\mathrm{M}_{1}$. Thus, amongst extant genera, the new species is closest to Maxomys.

The most ancestral genus of all rats is Karnimata from the Middle and/or Upper Miocene of the Siwaliks, IndoPakistan (Jacobs 1978; Jacobs \& Downs 1994). This primitive form has a distinct posterior cingulum with cusp $\mathrm{t} 8$ on $\mathrm{M}^{1}$, and frequently 
develops a cingulum between cusps $\mathrm{t} 4$ and $\mathrm{t} 8$. These characteristics are also shared with Progonomys from the Miocene Siwaliks. Various genera that diverged from Karnimata or Progonomys are found in the Upper Miocene of Africa, Europe and West to East Asia, and generally retain primitive features in common with Karnimata and Progonomys (Freudenthal \& Su'arez 1999; Storch \& Ni 2002). Maxomys shares basic molar characteristics with Karnimata, such as moderately high and cuspidated crown, chevron-shaped laminae, and $\mathrm{M}^{1}$ roots fewer than five. In contrast, the derived feature of Maxomys is characterized by comparatively simple molar patterns without any cingula and accessory structures.

Chaimanee (1998) reported three extinct Pliocene genera from central Thailand. Amongst them, Prohadromys and Saidomys are from the Upper Pliocene to Lower Pleistocene. These genera are phylogenetically close to extant Hadromys, which differs from Maxomys in that the first and second cusp rows on $\mathrm{M}^{1}$ of Hadromys form a symmetrical arch pattern. Another genus, Ratchaburimys, has also been found in the same horizon in Thailand and is described as a genus closely related to Millardia or Maxomys. Ratchaburimys and its only known species, $R$. ruchae, is characterized by the presence of stephanodont crests with each cusp and nearly vertical orientation of the wear facets on $\mathrm{M}^{1}$ and $\mathrm{M}_{1}$. These features are absent in living Maxomys and are also missing from the fossil specimens from the Gwebin area. The enamel patterns of Ratchaburimys lower molars are very similar to those of specimens examined in the present study, while the enamel patterns of upper molars indicate that the examined specimens are closer to Maxomys than to Ratchaburimys.

Maxomys is one of the most diverse genera in SouthEast Asia, and includes 17 species (Musser et al. 1979). The species from the Gwebin area resembles M. rajah and $M$. surifer in tooth measurements, but is classified as a new taxon, Maxomys pliosurifer sp. nov., based on several differences between the examined specimens and all known species of Maxomys. M. pliosurifer differs from some extant species in that it has four roots on $\mathrm{M}^{1}$, while extant species, including M. alticola, M. bartelsii, $M$. baeodon, M. inflatus, M. moi, M. ochraceiventer and M. panglima, have three roots. 
The number of roots on $\mathrm{M}^{1}$ of $M$. rajah and $M$. surifer varies between three and four, but is usually four (Musser et al. 1979). M. dollmani and M. musschenbroekii differ from $M$. pliosurifer in that they lack cusp $\mathrm{t} 3$ on $\mathrm{M}^{2}$. The other extant species are distinguished from $M$. pliosurifer by rarely having anterior or posterior cusplets on the labial side of $\mathbf{M}_{3}$. An anterocentral cusp on $\mathbf{M}_{1}$ is also rare in all extant species. The anterocentral cusp is sometimes present on $\mathrm{M}_{1}$ of $M$. surifer, but it is much smaller than that of $M$. pliosurifer. Cusp t9 of $M$. pliosurifer is larger than that of $M$. surifer, especially on $\mathrm{M}^{2}$.

In summary, Maxomys pliosurifer sp. nov. from the Gwebin area retains plesiomorphic features that are shared with the primitive genus Karnimata: $\mathbf{M}^{1}$ moderately high-crowned and cuspidate with chevron-shaped laminae, no $\mathrm{t} 1$ bis or $\mathrm{t} 2$ bis, cusp $\mathrm{t} 4$ not connected to cusp $\mathrm{t} 8$, neither cusp $\mathrm{t} 7$ nor a cingulum between $\mathrm{t} 4$ and $\mathrm{t} 8$, relatively small cusp $\mathrm{t} 9$ between $\mathrm{t} 6$ and $\mathrm{t} 8$, less than five roots; $\mathrm{M}^{2}$ with distinct cusp $\mathrm{t} 3$, three roots; $M_{1}$ with trapezoidal outline, chevron-shaped laminae, small anterocentral cusp, anterolingual cusp almost as large as anterolabial cusp, posterior cingulum elongated labiolingually; $\mathrm{M}_{2}$ with moderately large anterolabial cusp, distinct posterior cingulum; and $\mathrm{M}_{3}$ with anterolabial cusp.

Synapomorphic features between Maxomys pliosurifer and the other species of Maxomys are: $\mathrm{M}^{1}$ with cusp $\mathrm{t} 1$ displaced posteriorly, cusp $\mathrm{t} 3$ reduced, no posterior cingulum; $\mathbf{M}^{2}$ with strongly reduced cusp $\mathrm{t} 9$, no posterior cingulum; $\mathbf{M}^{3}$ without cusp t3; and $\mathrm{M}_{1}$ and $\mathrm{M}_{2}$ with accessory cusplets only at the posterolabial side. Maxomys pliosurifer has the following apomorphic features amongst Maxomys species: $\mathrm{M}^{1}$ and $\mathrm{M}^{2}$ with weak distal stephanodont crests, as in Ratchaburimys; and $\mathrm{M}^{3}$ with strongly developed cusp $\mathrm{t} 1$. The root number of $\mathrm{M}^{1}$ possibly indicates that $M$. pliosurifer, with four roots, is more derived than the species with three roots, although living $M$. surifer shows variation in root number between three and four.

Stratigraphical and geographical distributions. UpperPliocene of central Myanmar. 
Genus Rattus Fischer de Waldheim, 1803

Type species. Rattus rattus Linnaeus, 1758.

Rattus jaegeri Chaimanee, 1998

(Figs 5C, 6C, 8H-M)

1998 Rattus jaegeri Chaimanee: 131, pl. 9.

Material. A right $\mathrm{M}^{1}$ (IR 2108); three left $\mathrm{M}^{1}$ (IR 2106, IR 2548, IR 2832); a right $\mathrm{M}^{2}$ (IR 2555); a left mandible with $\mathrm{M}_{1}-\mathrm{M}_{3}$ (IR 1929).

Locality. $\operatorname{Mg} 1 / 2$.

Measurements. See Supplemental Appendix 2.

Description. The specimens are teeth of a medium-sized murid that is almost as large as Maxomys pliosurifer sp. nov. described above. $\mathrm{M}^{1}$ has an oval-shaped outline in occlusal view, but is not expanded labiolingually like in Hadromys. It has two chevron-shaped laminae and a posterior lamina without cusp t7. The first row is composed of cusps $\mathrm{t} 1$ to $\mathrm{t} 3$ and is symmetrical around cusp $\mathrm{t} 2$. Cusp $\mathrm{t} 1$ is as large as cusp $\mathrm{t} 3$, and they are situated on the horizontal. There is no accessory cusp on the anterior wall of this chevron. The second row including cusps t4 to t6 has almost the same characteristics as the first row. The cusps on the first and second rows are not connected with each other because there is a gap between the two rows. The third row is composed of well-developed $t 8$ and cuspidate $t 9$ cusps that do not connect to the cusps on the second row, even at a later wear stage. Cusp t9 is situated in the same horizontal position as cusp t8. A tiny, but distinct, posterior cingulum is 
always present with cusp t8. The radical part is anchored by five roots: anterior, posterior, labial and two lingual roots.

$\mathrm{M}^{2}$ has a rectangular occlusal outline. Cusps $\mathrm{t} 1$ and $\mathrm{t} 3$ are well developed on the anterior side. The anterior wall of cusp $t 1$ reaches anteriorly to that of cusp $t 3$. The medium row has the same pattern as the first and second rows of $\mathbf{M}^{1}$. Cusp $\mathrm{t} 4$ is as large as cusp t6 and does not connect with the anterior and posterior cusps. The posterior row is formed by the large cusp t8 and slender cusp $t 9$, as in $\mathbf{M}^{1}$. Cusp $t 8$ has a small posterior cingulum as well as $\mathbf{M}^{1}$.

The lower tooth row is observed in IR 1929, but its mandibular body is mostly broken (Fig. 6C). The teeth of IR 1929 show a late stage of wear. $M_{1}$ has a trapezoidal outline in occlusal view, and the anterior width is shorter than the posterior width. The occlusal enamel of $\mathrm{M}_{1}$ shows a basic murid pattern that is composed of three chevrons and a posterior cingulum. The first chevron is formed by an anterolabial cusp and an anterolingual cusp, crossing at an acute angle to each other. The anterolingual cusp is larger than the anterolabial cusp. The second chevron is composed of the protoconid and the metaconid that are connected to the first chevron at their anterior walls. The second chevron does not join with the third chevron. The posterolabial cusplet is present and connected with the hypoconid on the third chevron. The posterior cingulum is large, triangular and elongated labiolingually.

$\mathrm{M}_{2}$ has a square outline in occlusal view. The occlusal enamel pattern is composed of two chevrons and a posterior cingulum. The protoconid on the first chevron is larger than the metaconid on the other side. There is a small anterolabial cusp in front of the protoconid. The second chevron is isolated from the first chevron and has a mesial mure between the hypoconid and the entoconid. The posterolabial cusplet is appears to be present but is very small. The posterior cingulum is transversely wide. The first chevron is as wide as the second chevron.

$\mathrm{M}_{3}$ is very simple and is composed of two laminae. There is no anterolabial cusp. The posterior part is relatively large and has a semicircular outline with tiny projections on the labial and lingual sides. These laminae are not connected with each 
other.

Remarks. The examined specimens are allocated to a species of medium-sized rats that are characterized by symmetrical chevron-shaped laminae on $\mathbf{M}^{1}$, the presence of well-developed cusp t9 and posterior cingula on the upper molars, and the absence of cusp t7. These features represent primitive species of rats and mice, such as Antemus and Progonomys from the Middle to Upper Miocene (Jacobs 1978). However, the five-rooted $\mathrm{M}^{1}$ of the examined specimens is relatively derived, differing from all primitive species from the Miocene. The extinct Pliocene species from Thailand include Ratchaburimys, Prohadromys and Saidomys (Chaimanee 1998). Ratchaburimys is distinguished from the present specimens in that it has asymmetrical laminae on $\mathrm{M}^{1}$ and lacks a posterior cingulum. Prohadromys and Saidomys share molar characteristics with the species from the Gwebin area. Saidomys natrunensis from the Middle Pliocene of Egypt also has a symmetrical form and distinct posterior cingulum on $\mathrm{M}^{1}$ (Slaughter \& James 1979). The diagnostic feature of the Saidomys-Hadromys group is the presence of a labiolingually wide second lamina on the upper molars, with an approximate width-to-length ratio of 0.7 to 0.9 for $\mathrm{M}^{1}$. The ratio in the examined specimens is lower than that of species in the SaidomysHadromys group. Moreover, the large anterocentral cusp on $\mathrm{M}_{1}$ of S. natrunensis differs from the pattern observed in IR 1929.

The examined specimens are closest to the genus Rattus. Corbet \& Hill (1992) listed 29 extant genera of mice and rats from the Asian mainland and islands. Rattus is similar to Golunda, Hadromys, Haeromys, Kadarsanomys, Palawanomys, Srilankamys and Sundamys in that it has the combination of a symmetrical lamina on $\mathrm{M}^{1}$ and no cusp t7. Golunda differs from Rattus in that it has a relatively wide $\mathrm{M}^{1}$ outline in occlusal view. The distinctive feature for Golunda is very deep valleys between each cusp. The cusps are isolated or weakly connected, even if worn. Hadromys has posteriorly elongated cusp t6 and anteriorly approaching cusp t9, which are easily connected with each other on worn molars. On the other hand, Rattus 
usually has a deep gap between cusps t6 and t8 even after strong wear. Haeromys has a large posterior cingulum with cusp t8, as in some mice. However, it is different from Rattus in that it has a crest that connects cusps $t 4$ and $t 8$ on $\mathrm{M}^{1}$ and $\mathrm{M}^{2}$, and the anterocentral cusp is isolated from the first chevron on $\mathrm{M}_{1}$. Moreover, Haeromys commonly has $\mathrm{t} 2$ bis on the anterior side between cusps $\mathrm{t} 2$ and $\mathrm{t} 3$.

Kadarsanomys was originally described as Rattus, but was later separated from Rattus by Musser (1981a). The molar pattern of Kadarsanomys is very similar to that of Rattus, but the former has a larger cusp t8 and smaller cusp t9 than the latter (Musser \& Newcomb 1983). Palawanomys, described by the same author, is also similar to Rattus in terms of occlusal enamel patterns. Cusp t4 of Palawanomys is slightly separated from cusps 15 and t6 or is barely connected, compared to those of Rattus. Palawanomys is also distinguished from Rattus in that it has only a single root on the lingual side of $\mathrm{M}^{1}$. Srilankamys possesses relatively simple enamel pattern in upper molars. The laminae composed of each cusp form an arch shape rather than chevron shape represented by Rattus. Sundamys is a large-sized rat that has molars with almost the same pattern as Rattus. However, the first row of upper molars of Sundamys does not have a distinct constriction between each cusp, and occasionally reduces cusp $\mathrm{t} 3$.

Extant Rattus species are extremely diverse and more than 30 species are known from the Indomalayan Region (Corbet \& Hill 1992). However, the fossil species from the Gwebin area have a distinct posterior cingulum on both $\mathrm{M}^{1}$ and $\mathrm{M}^{2}$, indicating, according to Musser (1981b), that the species is relatively primitive. The examined specimens are classified as $R$. jaegeri, which is one of the most primitive species of Rattus from the Upper Pliocene to the Lower Pleistocene of Thailand (Chaimanee 1998; Chaimanee \& Jaeger 2001). R. jaegeri from Myanmar and Thailand have similar measurements and posterior cingula on their upper molars. Although $R$. jaegeri from the Gwebin area is slightly different from the holotype from Thailand in that has a more strongly developed posterior cingulum, this difference may be attributed to intraspecific variation, as similar cases are often observed in 
extant species of Rattus. Some unidentified species of Rattus are known from the Pleistocene of southern China, but they are much larger than R. jaegeri (Zheng 1993).

Stratigraphical and geographical distributions. UpperPliocene of central Myanmar and central Thailand.

\section{cf. Rattus sp. indet.}

(Figs 5D, 6D, 8N-T)

Material. A left maxilla with $\mathrm{M}^{1}-\mathrm{M}^{3}$ (IR 2551); a left $\mathrm{M}^{2}$ (IR 2833); a left mandible with $I_{1}$ and $M_{1}-M_{3}$ (IR 1964); a right mandible with $I_{1}$ and $M_{2}-M_{3}$ (M1-178); a right mandible with $\mathrm{M}_{2}-\mathrm{M}_{3}$ (IR 2056); a left mandible with $\mathrm{M}_{2}-\mathrm{M}_{3}$ (IR 2104); a right $\mathrm{M}_{3}$ (IR 2834).

Locality. $\mathrm{Mg} 1 / 2$ and Psw1.

Measurements. See Supplemental Appendix 2.

Description. IR 2551 is a relatively small maxilla with three complete molars in the early wear stage. Only the alveolar part of the maxillary bone is preserved. The crowns of the molars are cuspidate, but not very high.

The outline of $\mathrm{M}^{1}$ is oval in occlusal view. The occlusal surface has three rows forming a chevron shape that is anteroposteriorly shallow due to the early wear stage of the molar. The cusps on the first row are symmetrically arranged across cusp t2. Cusp t 3 is almost as large as cusp $\mathrm{t} 1$. Small $\mathrm{t} 2$ bis is present on the anterior wall between cusps $t 2$ and $t 3$. The second row is composed of cusps t 4 to t 6 and is isolated from the first and third rows by valleys. Cusp $t 4$ is slightly smaller than cusp t6, and both cusps are situated on the same horizon. The posterior row includes cusps $\mathrm{t} 8$ and $\mathrm{t} 9$ without a posterior cingulum. Cusp $\mathrm{t} 7$ is absent, but a vestigial 
crest runs from cusp t8 that is like a weak cingulum. Cusp t9 is between cusps $t 6$ and t8 and is not connected with cusp t6.

$\mathrm{M}^{2}$ has an inverted triangular shape in occlusal view. The crown is slightly longer than it is wide. Cusps $t 1$ and $\mathrm{t} 3$ are small, but distinct. The form of the middle row is similar to that of the second row on $\mathrm{M}^{1}$, but cusp $\mathrm{t} 5$ of the middle lamina is labiolingually planate. The posterior row on $\mathrm{M}^{2}$ is the same as on $\mathbf{M}^{1}$. Cusp $t 9$ approaches cusp t6. A vestigial crest runs from the lingual side of cusp t8 to cusp t4.

$\mathrm{M}^{3}$ has an inverted triangular outline that is long relative to its width. Cusps $\mathrm{t} 1$ and $\mathrm{t} 3$ are present as in $\mathrm{M}^{2}$, with cusp $\mathrm{t} 1$ much larger than cusp $\mathrm{t} 3$. The pattern of the middle row is a simple chevron shape, including cusps t 4 to t6. The posterior row is reduced and is isolated from the middle row by a deep gap.

The anterior parts, without processes, of two mandibles (IR 1964 and M1-178) are preserved. IR 1964 is identified as a young individual, based on the development of the lower incisor and molar state of wear. M1-178 is an old individual. The diastema is short and crosses at right angles the anterior edge wall of the alveolar bone. At this intersection point there is a small mental foramen. The lower masseteric crest is strong, while the upper masseteric crest is absent in IR 1964 because of the young age of the individual. The upper masseteric crest is observed in M1-178 but disappears towards the anterior portion. The mandibular depth below $\mathrm{M}_{1}$ is twice as large as that below $\mathrm{M}_{3}$. The alveolus of $\mathrm{M}_{1}$ has four holes for roots.

$\mathrm{M}_{1}$ has a trapezoidal occlusal outline that is nearly a triangle. The anterior width is much narrower than the posterior one. The occlusal enamel pattern is composed of three chevrons and a posterior cingulum. The anterolabial cusp on the first chevron is almost as large as the anterolingual cusp on the other side. The cross angle between the anterior cusps is obtuse. The second chevron is connected to the first chevron at the mesial point, creating an X-pattern. The protoconid on the second chevron is as large as the metaconid. There is a deep gap between the second and third chevrons. The hypoconid on the third chevron is slightly larger than the entoconid on the third 
chevron. The posterolabial cusplet is large and isolated from the hypoconid. The posterior cingulum is small and elliptical.

$\mathbf{M}_{2}$ has a square shape in occlusal view and is composed of two chevrons and a posterior cingulum. The protoconid is larger than the metaconid on the first chevron. There is a small anterolabial cusp with a cingulum around the labial base of the protoconid. The second chevron is isolated from both the first chevron and the posterior cingulum by deep valleys. The hypoconid on the second chevron is slightly larger than the entoconid. The posterolabial cusplet is usually present beside the hypoconid, but it is absent in IR 2056. The posterior cingulum is transversely elongate.

$\mathrm{M}_{3}$ has a comparatively simple enamel pattern that is composed of two transverse laminae. The anterolabial cusp is considerably reduced, but usually present as either a cingulum or a cusp. The protoconid on the first chevron is larger than the metaconid. The posterior part has a semicircular outline.

Remarks. The examined specimens are similar to a small-sized species of Rattus, characterized by the symmetrical form of $\mathrm{M}^{1}$, the presence of cusp $\mathrm{t} 3$ on $\mathrm{M}^{2}$ and $\mathbf{M}^{3}$, and the presence of an anterolabial cusp on $\mathbf{M}_{2}$ and $\mathbf{M}_{3}$. Differences between Rattus and other genera are noted in the above description of $R$. jaegeri. The upper molar row of the examined specimens has lengths that are within the range observed for $R$. exulans. Except for R. exulans and R. osgoodi, which are distributed in SouthEast Asia, the extant species of Rattus are much larger than the fossil forms from the Gwebin area. On the other hand, the small cingulum in place of cusp $\mathrm{t} 7$ is a primitive feature represented in some Miocene genera, such as Karnimata. Although it is difficult to identify the examined specimens at the species level because of insufficient material, this unique form from the Irrawaddy sediments may be a member of an early group of Rattus or a close relative.

\section{Stratigraphical and geographical distributions. UpperPliocene of central}


Myanmar.

Family Hystricidae Fischer de Waldheim, 1817

Genus Hystrix Linnaeus, 1758

Type species. Hystrix cristata Linnaeus, 1758.

Hystrix paukensis Nishioka et al., 2011

(Figs 9A-C, 10A)

2011 Hystrix paukensis Nishioka et al.: 919.

Material. A left $\mathrm{M}_{1 / 2}$ (M1-108); two right $\mathrm{M}_{3}$ (IR 1620, IR 1959).

Locality. Gbn5, GbnF1 andTBG1.

Measurements. See Supplemental Appendix 3.

Description. The isolated teeth are large and have hystricid enamel patterns. The crown of $\mathrm{M}_{1}$ or $\mathrm{M}_{2}\left(\mathrm{M}_{1 / 2}\right)$ is rectangular and is wider at the base. Crown height is moderately low (semihypsodont), and is shorter than crown length (Fig. 10A). There are four main folds and lophids on the occlusal surface. Fold I is complex and has united transverse and vertical folds. Fold II is L-shaped. Fold III runs transversely and opens to the lingual side. Fold IV is developed from the sinusid on the labial side, and extends from the labial wall to the posterior side. The ventral end of the sinusid reaches as far as one-half of the height of the tooth. There are four obvious roots on each lower molar. Interfacets are well developed on both the anterior and posterior sides. $M_{3}$ is similar to $M_{1 / 2}$ in occlusal enamel pattern, but is smaller than $\mathbf{M}_{1 / 2}$. The posterior wall of $\mathbf{M}_{3}$ leans anteriorly without an interfacet. The occlusal 
folds of IR 1959 are relatively complex and open to the outside due to weak wear.

Remarks. These specimens from the Gwebin area are assigned to Hystrix paukensis, the holotype (IR 0822) and an additional specimen (AML-N-IR 0036) of which are from the Chaingzauk area of central Myanmar. The species identification is based primarily on crown sizes and hypsodonty index (H/L). H. paukensis is one of the largest species of hystricid rodents. Although the holotype of H. paukensis lacks molars, its $\mathrm{P}_{4}$ and molar alveolar sizes are clearly larger than the maximum size of all extant and other extinct species of Hystrix (Nishioka et al. 2011). The molars of AML-N-IR 0036 are slightly longer than the molar alveoli of the holotype, and are almost as large as the examined specimens (Supplemental Appendix 3).

In Africa, several species of extinct hystricids are known from Plio-Pleistocene hominid sites (e.g. Greenwood 1955; Denys et al. 2011). Xenohystrix crassidens is the largest of all hystricids and is almost as large as Hystrix paukensis in some tooth measurements. Greenwood (1955) originally described and diagnosed Xenohystrix, but most dental and mandibular characters of this genus are quite similar to those of large-sized Hystrix species, such as H. refossa in Europe or its relatives. In fact the difference between $H$. paukensis and X. crassidens is not clear in terms of tooth measurements. According to Greenwood (1955), however, X. crassidens has a mandibular mental foramen approaching more anteriorly and tooth folds running more parallel to the labiolingual direction than the holotype and examined specimens of H.paukensis.

Hystrix paukensis has low-crowned cheek teeth that are different from hypsodont species such as $H$. refossa from the Late Pliocene to Holocene and all extant species. Low-crowned species (brachydont and semihypsodont forms) are known from the Miocene to Pliocene of Eurasia and Africa (Weers \& Rook 2003; Sen \& Purabrishemi 2010). Amongst these, four species (H. parvae, H. primigenia, H. sivalensis and $H$. trofimovi) are classified as brachydont, and six (H. caucasica, H. depereti, H. zhengi, $H$. aryanensis, $H$.gansuensis and $H$.lufengensis) as semihypsodont on the basis of their 
crown height index (H/L), although the ranges of H/L for the groups overlap one another (Nishioka et al. 2011). H. paukensis is similar to the semihypsodont species, or is at least different from the typical brachydont or hypsodont species.

Stratigraphical and geographical distributions. UpperMiocene to Upper Pliocene of central Myanmar.

\section{Hystrix sp. indet. (brachydont form)}

(Figs 9D-L, 10B)

Material. A left $\mathrm{P}^{4}$ (IR 2058); a right $\mathrm{M}^{1 / 2}$ (IR 1957); a left $\mathrm{M}^{1 / 2}$ (IR 1560); a right $\mathrm{dP}_{4}$ (IR 1958); a left $\mathrm{P}_{4}$ (IR 1927); a right $\mathrm{M}_{1 / 2}$ (M1-179-1); two left $\mathrm{M}_{1 / 2}$ (IR 1871, IR 2520); a left $\mathrm{M}_{3}$ (IR 2521).

Locality. Mg1/2, Gbn5 and TBG1.

Measurements. See Supplemental Appendix 3.

Description. All of the examined specimens are smallsized isolated cheek teeth with brachydont crowns. The upper cheek teeth have an enamel pattern that is typical of Hystrix: four transverse folds and a lingual sinus. All folds are isolated from the outside of the enamel. Fold III has a rotated L-shape. The sinus is shallow dorsoventrally. There are interfacets on the anterior and posterior sides of $M^{1 / 2}$ (IR 1560 and IR 1957), while $\mathrm{P}^{4}$ (IR 2058) only has a posterior interfacet. The radical part is anchored by two labial roots and a lingual root. On the lingual side, the crown is slightly higher than the length of the tooth ( $\mathrm{H} / \mathrm{L}$ ranges from 1.18 to 1.33$)$.

Deciduous premolar, IR 1958, is small and compressed labiolingually. It has a relatively complex enamel pattern. Two roots are present. The occlusal outlines of the lower cheek teeth are rectangular. Lower molars labiolingually expand at the anterior 
side. The occlusal enamel pattern of the lower cheek teeth is composed of a sinusid at the labial side and four to six folds that are isolated from the outside enamel. The sinusid does not exceed half of the crown height. All specimens, except the $\mathrm{M}_{3}$ (IR 2521), have interfacets on the anterior and/or posterior sides. IR 2521 is an unworn $M_{3}$ with very complicated enamel folds. There are four distinct roots on each lower cheek tooth. The crown on the labial side is generally not as high as the tooth is long (hypsodonty index is 0.60 to 1.14 ), as is representative of a brachydont or semihypsodont species of Hystrix (Fig. 10B).

Remarks. The tooth length and width of the examined specimens are close to those of an extant species, Hystrix brachyura (Online Supplementary Material Appendix 3). However, these specimens differ from all extant species of Hystrix in that they have relatively lower tooth crown, regardless of the stage of wear. Moreover, the examined specimens possibly have relatively complex enamel patterns in the lower cheek teeth, although the number and shape of the folds vary widely in extant species, depending on tooth condition. Low-crowned species are known from the Upper Miocene to Upper Pliocene of Eurasia, and most are relatively large in size. The examined specimens are as large as the smallest species, $H$. parvae, from the Upper Miocene of Europe, but $H$. parvae has a more complex enamel pattern than the species from the Gwebin area.

The ancestral species of hystricids, Sivacanthion complicatus, was discovered in the Middle Miocene of the Chinji Formation, Indo-Pakistan. Although this genus usually has much smaller teeth than Hystrix, a S. complicatus mandible with teeth (AMNH 39328) has some striking similarities with the fossil form from the Gwebin area. We do not believe the examined specimens are S. complicatus because of the large chronological gap. However, the fossil species from the Gwebin area shares primitive characteristics with Sivacanthion, and are clearly distinguished from derived species belonging to Hystrix from the Pleistocene and the Holocene. 
Stratigraphical and geographical distributions. UpperPliocene of central Myanmar.

\author{
Hystrix cf. brachyura Linnaeus, 1758
}

(Figs 9M, 10C)

1758 Hystrix brachyura Linnaeus: 57.

1811 Hystrix longicauda Marsden: 118.

1847 Acanthion hodgsoni Grey: 101.

1847 Hystrix alophus Hodgson: 771.

1851 Hystrix bengalensis Blyth: 170.

1866 Acanthochoerus grotei Grey: 310.

1871 Hystrix subcristata Swinhoe: 638.

1871 Hystrix mülleri Marshall: 235.

1879 Hystrix yunnanensis Anderson: 332.

1916 Acanthion klossi Thomas: 139.

1922 Acanthion millsi Thomas: 431.

1941 Hystrix vinogradovi Argyropulo: 90.

1972 Hystrix vinogradovi atavus Jánossy: 137.

1982 Hystrix vinogradovi kudarensis Baryshnikov \& Baranova: 47.

2003 Hystrix brachyura vinogradovi Baryshnikov: 45.

2003 Hystrix brachyura punungensis Weers: 222.

Material. A right $\mathrm{M}_{1 / 2}$ (M1-179-2).

Locality. $\operatorname{Mg} 1 / 2$.

Measurements. See Supplemental Appendix 3.

Description. It is difficult to observe the occlusal enamel pattern of M1-179-2 
because the specimen is covered by hard sedimentary matrix. There is no distinct difference between the examined fossil and living $H$. brachyura in occlusal outline and size. The tooth at the lingual side is curved sharply outwards. The crown on the lingual side is much higher (hypsodonty index is 1.80) than that of the brachydont form collected from the same location (Fig. 10). The sinus is shallow dorsoventrally, extending less than one fifth of the crown height. There are interfacets on the anterior and posterior sides. The tooth lacks divided roots.

Remarks. The examined specimen is close to Hystrix brachyura in size, which differs from the brachydont and semihypsodont species, including the Hystrix sp. indet., described in this study. In Eurasia and Africa, there are at least 11 known hypsodont species (H. brachyura, H. javanica, H. sumatrae, H. crassispinis, H. pumila, H. indica,

H.cristata, H.africaeaustralis, H.refossa, H.kiangsenensis and H. lagrelli) from the Upper Pliocene to the Holocene (Weers 2005). Hystrix javanica, H. sumatrae and $H$. crassispinis are distributed in Indonesia and the Philippines and are classified in the subgenus Acanthion, as is H. brachyura. The size ranges for the teeth of these species overlap each other, so it is difficult to distinguish between these species using only isolated teeth. On average, species of Acanthion are smaller than the other extant Hystrix species, such as $H$. indica, $H$. cristata and $H$. africaeaustralis (Weers 2005).

Hystrix refossa is an extinct species from the Upper Pliocene to Pleistocene of Europe and Asia. It includes many synonyms, such as $H$. magna from China and $H$. crassidens from India, and all of them are much larger than the examined specimens from the Gwebin area. Hystrix kiangsenensis from Pleistocene cave deposits in China is very similar to $H$. brachyura. Weers (2005) indicated that, on average, the teeth of $H$. kiangsenensis are significantly larger than those of $H$. brachyura. Hystrix lagrelli is also from the Pleistocene of China and is much smaller than H. brachyura. Hystrix subcristata is a common Pleistocene species in China, but was considered as a subspecies of H. brachyura by Weers (2005). Hystrix brachyura and H. subcristata cannot be distinguished from one another using only isolated teeth. Moe-Nyunt (1987) 
previously reported a species of Hystrix from the Gwebin area and documented the close relationship between the fossil species and $H$. subcristata. The present specimen certainly belongs to the extant species $H$. brachyura or one of its synonyms.

Stratigraphical and geographical distributions. UpperPliocene to Pleistocene of Eurasia, and Holocene of South-East Asia and southern China.

Family Spalacidae Gray, 1821

Genus Cannomys Thomas, 1915

Type species. Rhizomys badius Hodgson, 1841.

Cannomys cf. badius Hodgson, 1841 (Fig. 11)

1841 Rhizomys badius Hodgson: 60.

1842 Rhizomys minor Grey: 266.

1843 Rhizomys castaneus Blyth: 1007.

1915 Cannomys pater Thomas: 315.

1915 Cannomys plumbescens Thomas: 315.

1917 Cannomys lönnbergi Gyldenstolpe: 47.

Material. A left $\mathrm{M}^{1}$ (IR 2531); a left $\mathrm{M}^{2}$ (IR 2537); a right $\mathrm{M}^{3}$ (IR 2522); a right $M_{1}$ (IR 1956); two right $M_{2}$ (IR 2535, IR 2536); two right $M_{3}$ (IR 2103, IR 2530); a left $\mathrm{M}_{3}$ (IR 2102).

Locality. $\operatorname{Mg} 1 / 2$.

Measurements. See Supplemental Appendix 4. 
Description. Specimen IR 2531 is identified as an $\mathbf{M}^{1}$ that is broken in the posterior part, but appears to have a circular outline in occlusal view. At least three lophs are observed on the occlusal surface. The fold between the anteroloph and protoloph is divided into two islands: a short one on the lingual side and a long one on the labial side. The middle fold between the protoloph and metaloph is almost as long as the anterior fold. The labial end of the sinus reaches the half of the occlusal width. The tooth has four roots.

Specimen IR 2537 identified as an $\mathrm{M}^{2}$ and, although the posterior part is missing, all lophs are preserved. The occlusal surface is a rounded square and is composed primarily of three lophs. A small isolated fold is present at the centre of the protoloph and is like the small anterior fold on $\mathrm{M}^{1}$. The main fold between the protoloph and metaloph is connected to the sinus at the centre of the occlusal surface. The posterior fold between the metaloph and the posteroloph is isolated from the outside enamel. This fold bends slightly to the posterior side, forming an L-shape. Four roots are present on the radical face.

$\mathrm{M}^{3}$ is reduced considerably in size. The occlusal outline is triangular. The enamel pattern is composed primarily of three lophs and two folds. The most anterior loph, corresponding to the protoloph, is anteroposteriorly wide. This loph includes an additional isolated fold like that in $\mathrm{M}^{1}$ and $\mathrm{M}^{2}$. The sinus on the anterolingual side is connected to a triangular fold at the labial side. This fold transversely divides the metaloph from the protoloph. The metaloph is shorter than the protoloph. The other sinus opening to the posterolingual side forms a chevron that crosses labiolingually on the posterior occlusal surface. The posteroloph is labiolingually short. The tooth is composed only of the crown part without the root, probably because of the young age of the individual.

$\mathrm{M}_{1}$ is relatively high-crowned and rootless. The occlusal surface has a rounded rectangular shape and its anterior part is slightly narrower in the labiolingual direction than the posterior part. The occlusal enamel pattern includes five lophids and five labiolingually traversing folds. The fold below the anterolophid is relatively large and 
has a triangle outline. Mesolophid is present, and divides the anterolingual sinusid into two equally sized folds. The folds at the labial and lingual sides are anteroposteriorly shallow, opening to the outside of the enamel. The labial ends of the lingual folds approach the lingual ends of the labial folds at the centre of the occlusal surface, but they do not connect to each other. The crown is wider at the base than at the occlusal surface.

$\mathrm{M}_{2}$ is composed primarily of three lophids and three folds, but their patterns and occlusal outlines change considerably with wear. IR 2536 has a rectangular outline at an early wear stage. The anterior fold opens at the lingual side and crosses transversely. It has a small branch that extends posteriorly, dividing the middle lophid between mesolophid and hypolophid. After wear, these lophids are connected, as in IR 2535. The fold opening to the labial side is dorsoventrally deep. The folds on the other side are also well developed, but seemed to disappear at later wear stages. The posterolophid is relatively large and as wide as the anterior one. This lophid is connected to the hypolophid at the centre. IR 2535, at a later wear stage, is a rounded square in occlusal view. The occlusal pattern is much simpler and wider than that of IR 2536, which is at a younger stage. The posterior fold of IR 2535 has mostly disappeared, leaving a small isolated fold at the centre. There are four roots on IR 2535.

$\mathrm{M}_{3}$ is high-crowned and rootless because it is little worn. The occlusal surface has an inverted triangular shape, and is composed of three or four lophids. The fold between anterolophid and metalophid is shaped like a small ellipse. This fold is absent at the earliest wear stage in IR 2530. The fold between the metalophid and hypolophid crosses transversely from the lingual side to the anterolabial corner. The posterolophid is isolated from the hypolophid by a deep valley that crosses labiolingually. This valley reaches the base of the crown on the labial side but is relatively shallow on the lingual side. The anterior side has an interfacet, while the posterior side inclines anteriorly and does not have an interfacet. Only the anterior part of $\mathrm{M}_{3}$ is preserved in IR 2103. It has the same size and pattern as IR 2102. There are at least two main 
roots on IR 2102.

Remarks. The family Spalacidae includes four subfamilies: Myospalacinae, Spalacinae, Tachyoryctinae and Rhizomyinae. The examined specimens differ from Myospalacinae, Spalacinae and Tachyoryctinae in that they have a relatively high molar crown, $\mathbf{M}^{1}$ with four roots, $\mathrm{M}_{3}$ with isolated posterolophid, and $\mathrm{M}_{3}$ without mesolophid (Flynn 1990). Rhizomyinae includes two living genera, Rhizomys and Cannomys. Another extinct rhizomyine, 'Brachyehizomys', is known from the middle Pliocene of northern China (Teilhard de Chardin 1942), but this genus was later synonymized with Rhizomys by Flynn (1990). Miocene rhizomyines with primitive features have been found in the Upper Miocene of Indo-Pakistan and South China and have also been described as 'Brachyehizomys' (Flynn 1982).

The examined specimens from the Gwebin area share the following characteristics with Cannomys, as distinguished from 'Brachyehizomys' and Rhizomys: (1) smallsized teeth; (2) primarily three-crested $\mathbf{M}^{2}$ and $\mathbf{M}_{2}$; (3) relatively short $\mathbf{M}^{3}$ and $\mathrm{M}_{2}$; (4) no anterolophid on $\mathrm{M}_{2}$; and (5) reduced posterolophid on $\mathrm{M}_{3}$. Cannomys is a monotypic lineage that includes $C$. badius, and no fossil record for this genus has so far been reported. The fossil species from the Irrawaddy sediments is similar to the living $C$. badius in size (Supplemental Appendix 4), but also possesses some minor differences, such as the presence of an additional fold in the anterior loph and more complex folds in $\mathrm{M}_{1}$. Cannomys from the Upper Pliocene of Myanmar is probably not separated phylogenetically from the living form, given that the minor differences observed are changed by wear and/or intraspecific variation. In fact, in both living and fossil forms, wear induces strong variation in the enamel patterns of molars.

Stratigraphical and geographical distributions. UpperPliocene of central Myanmar, and Holocene of Nepal to north-western Vietnam (probably except central Myanmar). 
Family Sciuridae Gray, 1821 Genus Menetes Thomas, 1908

Type species. Sciurus berdmorei Blyth, 1849.

\section{Menetes sp. indet.}

(Fig. 12)

Material. Two left $\mathrm{P}_{4}$ (IR 2532, IR 2835); two left $\mathrm{M}_{1}$ (IR 2836, IR 2837); two left $\mathrm{M}_{2}$ (IR 2533, IR 2838); a right $\mathrm{M}_{3}$ (IR 2534).

Locality. $\operatorname{Mg} 1 / 2$.

Measurements. See Supplemental Appendix 5.

Description. The occlusal outline of $\mathrm{P}_{4}$ basically is a trapezoid that is almost a triangle. However, IR 2532 is wider than IR 2835 because of considerable wear. The crown is composed of four main cusps and crests that connect the cusps. The talonid basin is remarkable. Metaconid and hypoconid are well developed in both specimens, but the metaconid of IR 2532 is quite worn. There is a tiny paraconid between the metaconid and protoconid in IR 2835. The crest (posterolophid) between the hypoconid and entoconid is sharp, forming the posterior interfacet of the tooth. IR 2532 has anterior and posterior roots.

The occlusal surface of $M_{1}$ (IR 2836 and IR 2837) has a rounded square outline, and is composed of four remarkable cusps that surround a talonid basin. The metaconid is the largest cusp and is highly cuspidate at an early wear stage, but is strongly worn in IR 2837. Protoconid and hypoconid are also well defined in both specimens. There is a deep gap between these cusps. The entoconid is relatively small, presenting on a cingulum (posterolophid) that joins the metaconid and the hypoconid. The paraconid (or anterolophid) is strong on the anterolabial corner, and approaches the protoconid. 
The talonid basin is wide and deep. In IR 2836, two large roots are present.

Specimens IR 2533 and IR 2838 are identified as $\mathbf{M}_{2}$ and are not affected by strong wear. The occlusal outline appears to be a slender trapezoid. The four main cusps are equally well developed, as in $\mathrm{M}_{1}$. The entoconid is sharp and more distinct than that of $\mathrm{M}_{1}$. The paraconid is strong at the anterolabial side, and is connected to the protoconid and metaconid by crests. The crest on the lingual side is weaker than that on the labial side. The posterolophid curves strongly on the posterior wall and connects to the hypoconid and the entoconid. The posterior part is surrounded by the hypoconid and entoconid has a labiolingually elongated ellipse shape in occlusal view. The talonid forms some sinusids, rather than a basin, because of the unworn state of the tooth. One of these sinusids crosses labiolingually, dividing the occlusal enamel pattern into an anterior part (protoconid and metaconid) and a posterior part (hypoconid and entoconid). Roots are not developed, due to the young age of the individual.

Like the $\mathrm{M}_{2}$ specimen, $\mathrm{M}_{3}$ (IR 2534) is also an unworn tooth. The occlusal surface has a very slender triangular outline in occlusal view. The main cusps are strong, but are developed like a bunodont. The metaconid is placed posteriorly and is not anteroposteriorly separated from the protoconid. Between the metaconid and hypoconid, there are some small cusps, including entoconid, lined up on the outer crest. Paraconid is weakly present. The talonid basin is anteroposteriorly slender, opening to the outside as sinusids. The tooth lacks its root.

Remarks. The examined specimens have the basic molar pattern of sciurids, but they are distinguished from flying squirrels, subfamily Pteromyinae, in that they have a relatively simple talonid basin without complex crenulations. Living non-flying squirrels are classified in the subfamily Sciurinae and include seven tribes in Asia: Sciurini, Xerini, Marmotini, Tamiini, Ratufini, Nannosciurini and Funambulini (McKenna \& Bell 1997). The examined specimens have a relatively simple enamel pattern with a wide talonid basin that is representative of Sciurus belonging to the 
Sciurini, but the examined molars have stronger entoconid and paraconid on the anterolabial side than those of Sciurus. These characteristics are common in some species in the Nanosciurini tribe. Ground squirrels, or the tribes Xerini and Marmotini, have relatively short $\mathrm{M}_{3}$ and molars with shallow talonid basins and a distinct crest connecting the protoconid and metaconid (e.g. Cuenca Bescós 1988; Lacomba Andueza 1988).

The tribe Nannosciurini is a diverse group of squirrels in South-East Asia, and is represented by the genera Callosciurus and Tamiops. Chaimanee (1998) reported nannosciurine sciurids from Plio-Pleistocene sediments of Thailand, and described the cheek teeth of five genera: Nannosciurus, Rhinosciurus, Tamiops, Callosciurus and Menetes. Amongst these, Menetes is the closest to the fossil specimens from Gwebin in being of medium size and with prominent paraconid and entoconid in its molars. In contrast, the metaconid on M3 of Callosciurus approaches more anteriorly than that of either Menetes or IR 2534. Tamiops is similar to Menetes in these features, but the former has a smaller crown than the latter (Zheng 1993; Chaimanee 1998). A single species of genus Menetes is known. This species, M. bedmorei, is broadly distributed in continental South-East Asia, and is close to the examined fossil form in terms of lower molars.

\section{Stratigraphical and geographical distributions. UpperPliocene of central} Myanmar.

\section{Discussion}

\section{Biostratigraphical comparison of rodent faunas from Asia}

The rodent assemblage from Gwebin includes four murid, three hystricid, one spalacid, and one sciurid species. These species were collected from five localities in the Gwebin area. Most of the specimens were recovered from the sediments at 
$\mathrm{Mg1/2}$, and only Hystrix paukensis was not included in the fossil assemblage from Mg1/2 (Supplemental Appendix 1). The absence of H. paukensis from Mg1/2 is probably due to a taphonomic or collecting bias rather than age differences between localities; hence the fossil rodents discovered from the Gwebin area comprise a single fossil assemblage. In fact, Hystrix sp. indet. (brachydont form), which is intermediate in size between $H$. paukensis and the other rodents, was recovered from both $\mathrm{Mg} 1 / 2$ and the other localities.

The Gwebin rodent assemblage is characterized by the coexistence of primitive species that survived from the Late Miocene or Early Pliocene, and members of the earliest lineages directly linking to extant rodents in SouthEast Asia (Table 3). None of the species described in this study has been previously found in the Indian subcontinent. The Siwalik Hills in the Indo-Pakistan area contain some of the bestknown Neogene fossil localities and have yielded various rodent fossils (Jacobs 1978; Flynn 1982; Patnaik 1997, 2001, 2003, 2013; Patnaik \& Nanda 2010). The PlioPleistocene rodent fauna from the Siwalik Groups is composed primarily of genera corresponding to extant species that are distributed in South Asia at the present day, such as Golunda, Nesokia and Bandicota. These genera have not been found in the Irrawaddy sediments, although some of them are known from the Pleistocene to the Recent of South-East Asia and southern China (Corbet \& Hill 1992; Chaimanee 1998; Jin et al. 2009).

The Gwebin rodent assemblage is biostratigraphically correlated with the Upper Pliocene through the Lower Pleistocene of Thailand due to the presence of Rattus jaegeri, which is one of the earliest forms of the genus (Chaimanee 1998; Chaimanee \& Jaeger 2001). Moreover, the earliest appearances of Maxomys and Hapalomys are in the Late Pliocene in Thailand. At the genus level, the Gwebin rodent assemblage shares the presence of Hapalomys and Hystrix with Early Pleistocene faunas of southern and central China (Zheng 1993; Jin et al. 2009).

Maxomys first occurred in the Late Pliocene of continental South-East Asia and diversified within this region (Chaimanee 1998). Ratchaburimys ruchae is 
phylogenetically close to the lineage of Maxomys, also found in the Upper Pliocene to the Lower Pleistocene of Thailand, and is associated with the extant species, Maxomys surifer. Recent molecular studies of the Rattus sensu lato group have suggested that the clade of Maxomys diverged from that of Rattus about 7.6 to 6.1 Ma, and that Maxomys speciated in South-East Asia about 4.8 to 3.9 Ma (Ruedas \& Kirsch 1997). The timing of these divergences is coincident with the first appearance of Ratchaburimys ruchae and M. surifer in Thailand. A species of Maxomys from the Gwebin area is morphologically more primitive than any extant species of the genus. Thus, the divergence time of the Gwebin form from the clade of extant Maxomys is estimated to be younger than 7.6-6.1 Ma and possibly older than 4.8-3.9 Ma, based on molecular data. This estimate suggests that the geological age of the Gwebin fauna is younger than 7.6-6.1 Ma.

A later age is indicated by the presence of Rattus than is indicated by the presence of Maxomys. The oldest species of the genus is Rattus jaegeri, which was from the Upper Pliocene (3.5-2.5 Ma) of the Khao Sangam Limestone Cave in central Thailand (Chaimanee 1998). R. jaegeri was also found in the Gwebin area, suggesting biostratigraphical correlation between these localities. On the basis of fossil evidences in Thailand, Chaimanee \& Jaeger (2001) proposed that the other species of Rattus in SouthEast Asia diverged from a single primitive species in the Pliocene. This hypothesis is supported by molecular studies of extant species of Rattus sensu lato, which demonstrated that speciation within Rattus occurred around $2.5 \mathrm{Ma}$ in South-East Asia (Verneau et al. 1997). R. jaegeri and a species closely related to Rattus (cf. Rattus sp. indet.) were found in the Gwebin area, but both of these differ from extant species of the genus. The Gwebin species may be included as a member of the ancestral group of Rattus, diverging before $2.5 \mathrm{Ma}$, as estimated by the previous molecular study.

Cannomys from the Gwebin area is the first fossil record of this genus from the Pliocene to the Pleistocene. The genus is interpreted as the sister clade of Rhizomys, and Rhizomys and Cannomys probably diverged by at least $4 \mathrm{Ma}$, as the oldest fossil 
of Rhizomys is reported to be of this age (Flynn 1990). Fossils of Rhizomys (or Brachyrhizomys) are relatively common after the Late Pliocene of Indo-Pakistan and China, but none older than $4 \mathrm{Ma}$ has been found. This palaeontological evidence suggests that Cannomys was unlikely to have been present before $4 \mathrm{Ma}$.

Fossils of Hystrix paukensis have low-crowned teeth and were previously discovered in the Upper Miocene to Lower Pliocene Irrawaddy sediments of the Chaingzauk area (Nishioka et al. 2011). H. paukensis was also recovered from the Upper Irrawaddy stage of the Gwebin area. The Upper Irrawaddy sediments yielded another brachydont species of Hystrix and $H$. cf. brachyura with hypsodont teeth. The low-crowned morphology is generally accepted as a primitive feature in Hystrix species. Early forms of Hystrix such as H.parvae and H.primigenia had low-crowned teeth, while later forms, including extant species, acquired much higher crowned teeth that lacked distinct roots (e.g. Sen 1999). Many researchers consider that the increase of crown height in Hystrix occurred in the Late Miocene because semihypsodont species, such as $H$. lufengensis and $H$. aryanensis, first appeared in the middle Late Miocene of southern China and western Asia (Afghanistan and Iran), respectively (Sen 2001a, b; Weers \& Rook 2003; Sen \& Purabrishemi 2010).

In Eurasia, most low-crowned (brachydont and semihypsodont) species disappeared and were replaced by hypsodont species by the latest Pliocene. Therefore, discovery of low-crowned and hypsodont forms suggest Mio/Pliocene and Pleistocene/Holocene ages, respectively. The co-existence of both types in the Gwebin rodent assemblage indicates that the assemblage contains the last occurrence of the low-crowned species and/or the oldest record of the hypsodont species. Moreover, the geological age of the Gwebin fauna is considered to be Late Pliocene rather than Early Pleistocene because lowcrowned Hystrix paukensis or $H$. sp. indet. are considerably more common than hypsodont $H$. cf. brachyura amongst specimens collected from the Gwebin area.

The rodent assemblage from the Gwebin area suggests that the sediments date from the Middle to Late Pliocene, not older than approximately $4 \mathrm{Ma}$ and younger than approximately $2.5 \mathrm{Ma}$, as indicated by the biostratigraphy and divergence time of 
rodents in South-East Asia. This range is consistent with the geological age estimated by biostratigraphical comparisons using large mammals. However, the Gwebin rodent assemblage includes some derivedspecies that are similar to living forms, such as Hapalomys longicaudatus and Hystrix brachyura. This suggests that rodent lineages directly linked to extant species in continental South-East Asia occurred at least in the Late Pliocene.

\section{Dispersion of rodents and geographical factors}

The distribution of terrestrial mammals is usually affectedby geographical events, such as the formation of river barriers and sea level changes. The Gwebin rodent fauna includes four species, Hapalomys cf. longicaudatus, Maxomys pliosurifer sp. nov., Hystrix cf. brachyura and Cannomys cf. badius, that are similar to extant forms distributed in the Indochinese Division. The IUCN Red List data (accessed on 4 January 2013) indicate that these rodents appear to be bordered by a combination of nine large rivers: the Yellow, Yangtze, Pearl, Red, Mekong, Salween, Irrawaddy, Brahmaputra and Ganges rivers (Aplin \& Lunde 2008; Aplin et al. 2008a, b; Lunde \& Aplin 2008; Lunde et al. 2008; see also Fig. 13). Uplift of the IndoBurma Ranges along the western border of Myanmar may be another factor that affected geographical barriers to mammal distribution. However, some species of rodents, such as Cannomy badius, live in the forests covering the Indo-Burma Ranges. Therefore, our discussion of the dispersion time of the rodents found in the Upper Pliocene Irrawaddy sediments will focus on the timing of the appearance of the river barriers.

River barriers for rodents in the Indochinese Division were formed by rivers that have flowed in their present courses since the uplift of the Himalaya-Tibetan Plateau during the Oligo-Miocene. The timing of their appearance was reviewed by Meijaard \& Groves (2006). The main large rivers flowing in continental South-East Asia closely converge in the upper region of the rivers, and are considered to have existed since the Early Miocene (Hallet \& Molnar 2001). Clark et al. (2004) reconstructed river courses in the Neogene of eastern Tibet, based on the evidence of river capture 
and reversal events. Later, Clift et al. (2006, 2008) reconsidered the timing of capture in terms of the Red River. The reconstruction of river capture patterns shows that before the Early Miocene, four large rivers merged into a single course on the Red River and flowed to the South China Sea. Chinese rivers, such as the Yangtze River, likely flowed southwards until this period and connected with the Red River (Clift et al. 2008). Since the Miocene there has been a wide barrier for small mammals between continental South-East Asia and southern China that is formed by the Red River and its neighbouring rivers.

The main rivers in the Indochinese Division began to separate from the Red River in the Early Pliocene, although the Brahmaputra River may have been captured by the Irrawaddy River, flowing into the Andaman Sea until the Middle Pliocene (Clark et al. 2004). The Mekong and Salween rivers likely flowed as a single course into the Chao Phraya River until the Pleistocene (Hutchinson 1989). Based on these data, the Late Pliocene rodents in central Myanmar were separated from those in South Asia and southern China, like rodents are at present, due to the presence of river barriers.

The four rodent species from the Gwebin area seem to have originated in the Indochinese Division during theMiocene or Pliocene as the distribution of most living and fossil species is restricted to this region (Fig. 13). Thesciurid Menetes described in this study, although not yet identified to species level, is also distributed only in continental South-East Asia. The earliest dispersion time of these rodents is considered to have been before the EarlyPliocene, when the main rivers in SouthEast Asia beganto flow southwards after separating from the Red River.Based on the distribution pattern of Hapalomys species and Hystrix brachyura, these species would have dispersed from South-East Asia into southern China beforethe palaeo Red River barrier was formed in the OligoMiocene. However, there is no fossil record of these species from the Mio-Pliocene, even in well-studied localitiesin China (Zheng 1993; Jin et al. 1999; Lucas 2001; Qi \&Ni 2006). Furthermore, the lack of a fossil record for thesetaxa in South Asia supports the hypothesis that they didnot extend west of the Ganges River during the Miocene(Jacobs 1978; Patnaik 2003; 
Patnaik et al. 2008).

Hapalomys delacouri, Hystrix brachyura and Maxomys surifer were probably dispersed between the continent and surrounding islands by a land bridge when sea level fell during glaciations. They may have migrated between South-East Asia and southern China by a land bridge via Hainan Island in the Early Pleistocene when sea levels dropped (Voris 2000; Naish \& Wilson 2009; Zhang et al. 2009). However, the discovery of these rodents in the Upper Pliocene Irrawaddy sediments indicates that the four rodent species dispersed within continental SouthEast Asia before they spread over land bridges in the Pleistocene. Therefore, the early group of living rodents in the Indochinese Division likely dispersed within continental South-East Asia during the Pliocene, and they certainly existed in the Late Pliocene of the western coast of the Irrawaddy River.

\section{Conclusions}

The rodent assemblage from the Upper Pliocene Irrawaddy sediments discovered in the Gwebin area includes four murids (Hapalomys cf. longicaudatus, Maxomys pliosurifer sp. nov., Rattus jaegeri and cf. Rattus sp. indet.), three hystricids (Hystrix paukensis, Hystrix sp. indet. (brachydont form) and Hystrix cf. bracyura), one spalacid (Cannomys cf. badius) and one sciurid (Menetes sp. indet.). This assemblage is characterized by the coexistence of primitive species that survived from the MioPliocene and derived species that correspond to living species in continental SouthEast Asia. The faunal composition, and its estimated age, indicate that the rodent assemblage from the Gwebin area represents one of the earliest dispersal groups in the Indochinese Division, and were isolated from other rodent fauna in South Asia and southern China by river barriers. This geographical isolation is correlated with the presence of many endemic species in the Gwebin rodent assemblage. The discovery of rodent fossils in the Upper Pliocene Irrawaddy sediments fills a chronological and geographical gap in the Pliocene fossil record of southern Asia, and adds to contemporaneous data for the fossil records in Thailand. 


\section{Acknowledgements}

We thank personnel from the Ministry of Education, Myanmar for providing the permission for fieldwork and assistance. We also thank personnel from the Department of Archaeology, National Museum and Library (Ministry of Culture, Union of Myanmar) for help during the palaeontological expedition in Myanmar. Other members of the Myanmar-Japan palaeontological expedition team kindly helped us to arrange the field research and collect fossil specimens. Special thanks are due to Associate Professor Rajeev Patnaik (Panjab University, Chandigarh) and Prof. Chang-zhu Jin (Institute of Vertebrate Palaeontology and Palaeoanthropology, Beijing) for their helpfulness in accessing comparative specimens and advice. We would also like to thank the staff of the Bagan Archaeological Museum (Bagan), the National Museum (Yangon), the Bombay Natural History Society (Mumbai), the Khorat Fossil Museum (Nakhon Ratchasima), the Kyoto University Museum (Kyoto), the American Museum of Natural History (New York), and the Senckenberg Forschungsinstitut und Naturmuseum (Frankfurt). The present study was financially supported in part by the ITPHOPE and AS-HOPE programs of the Japan Society for the Promotion of Science (JSPS); Grant-in-Aid for Scientific Research to MT [grant number 20405015]; Grant-inAid for JSPS Fellows to YN [grant number 24.3100]; Global COE Grant A06 to Kyoto University.

\section{References}

Anderson, J. 1879. Anatomical and zoological researches: comprising an account of the two expeditions to western Yunnan in 1868 and 1875; and a monograph of the cetacean genera, Platanista and Orcella. Bernard Quaritch, London, 985 pp.

Aplin, K. P. \& Lunde, D. P. 2008. Hapalomys longicaudatus. IUCN Red List of Threatened Species. Version 2012. 2. Updated at: http://www.iucnredlist.org, accessed 4 January 2013.

Aplin, K. P., Lunde, D. P. \& Musser, G. G. 2008a. Maxomyssurifer.IUCNRedList 
of Threatened Species. Version 2012.2. Updated at: http://www.iucnredlist.org, accessed 4 January 2013.

Aplin, K. P., Lunde, D. P., Musser, G. G., Frost, A. \& Molur, S. 2008b. Cannomys badius. IUCN Red List of Threatened Species. Version 2012. 2. Updated at: http://www. iucnredlist.org, accessed 4 January 2013.

Argyropulo, A. 1941. Rodents and insectivores of the Quaternary fauna of Binagady. Priroda, 3, 88-91. [in Russian].

Badgley, C., Barry, J. C., Morgan, M. E., Nelson, S. V.,Behrensmeyer, A. K., Cerling, T. E. \& Pilbeam, D. 2008. Ecological changes in Miocene mammalian record show impact of prolonged climatic forcing. Proceedings of the National Academy of Sciences, 105, 12145-12149.

Barry, J. C., Morgan, M. E., Flynn, L. J., Pilbeam, D., Behrensmeyer, A. K., Raza, S. M., Khan, I. A., Badgley, C., Hicks, J. \& Kelley, J. 2002. Faunal and environmental change in the late Miocene Siwaliks of northern Pakistan. Paleobiology, 28, 1-71.

Baryshnikov, G. F. 2003. Pleistocene small porcupine from the Ural Mountains, Russia, with note on taxonomy of Hystrix vinogradovi (Rodentia, Hystricidae). Russian Journal of Theriology, 2, 43-47.

Baryshnikov, G. F. \& Baranova, G. I. 1982. On the finding of the Vinogradov porcupine in the Caucasian Paleolithic. Trydy Zoologicheskogo Instituta AN SSSR, 115, 46-53. [In Russian].

Bender, F. 1983. Geology of Burma. Gebruder Borntraeger, Berlin, 293 pp.

Blyth, E. 1843. Rhizomys from Arracan. Journal of the Asiatic Society of Bengal, 12, 1006-1007.

Blyth, E. 1849. Note on the sciuri inhabiting Ceylon, and those of the Tenasserim provinces. Journal of Asiatic Society of Bengal, 18, 600-603.

Blyth, E. 1851. Report on the Mammalia inhabiting Ceylon. Journal of the Asiatic Society of Bengal, 20, 153-185.

Blyth, E. 1859. Proceedings of the Asiatic Society: Report of the Curator, Zoological 
Department, for February to May Meetings, 1859. Journal of the Asiatic Society of Bengal, 28, 271-298.

Bowdich, T. E. 1821. An analysis of the natural classifications of Mammalia: for the use of students and travellers. J. Smith, Paris, $115 \mathrm{pp}$.

Chaimanee, Y. 1998. Plio-Pleistocene rodents of Thailand. ThaiStudies in Biodiversity, $3,1-303$.

Chaimanee, Y. \& Jaeger, J.-J. 2001. Evolution of Rattus (Mammalia, Rodentia) during the Plio Pleistocene in Thailand.Historical Biology, 15, 181-191.

Chaimanee, Y., Jaeger, J.-J. \& Suteethorn, V. 1993. Pleistocene microvertebrates from fissure-fillings in Thailand. Journal of Southeast Asian Earth Sciences, 8, 4548.

Chaimanee, Y., Suteethorn, V., Triamwichanon, S. \& Jaeger, J.-J. 1996. A new stephanodont Murinae (Mammalia, Rodentia) from the early Pleistocene of Thailand and the age and place of the Rattus adaptive radiation in South East Asia. Comptes rendus de l'Académie des sciences, Série 2, 322, 155-162.

Chavasseau, O., Chaimanee, Y., Soe-Thura-Tun, AungNaing-Soe, Barry, J. C., Marandat, B., Sudre, J., Marivaux, L., Ducrocq, S. \& Jaeger, J.-J. 2006. Chaungtha, a new Middle Miocene mammal locality from the Irrawaddy Formation, Myanmar. Journal of Asian Earth Sciences, 28, 354-362.

Clark, M. K., Schoenbohm, L. M., Royden, L. H., Whipple, K. X., Burchfiel, B. C., Zhang, X., Tang, W., Wang, E. \&Chen, L. 2004. Surface uplift, tectonics, and erosion of eastern Tibet from large scale drainage patterns. Tectonics, 23 (1), TC1006.

Clift, P. D., Blusztajn, J. \& Nguyen, A. D. 2006. Large-scaledrainage capture and surface uplift in eastern Tibet-SW China before 24 Ma inferred from sediments of the Hanoi Basin, Vietnam. Geophysical Research Letters, 33(19), L19403.

Clift, P. D., Long, H. V., Hinton, R., Ellam, R. M., Hannigan, R., Tan, M. T., Blusztajn, J. \& Duc, N. A. 2008. Evolving east Asian river systems reconstructed by trace element and $\mathrm{Pb}$ and $\mathrm{Nd}$ isotope variations in modern and ancient Red 
River Song Hong sediments. Geochemistry, Geophysics, Geosystems, 9(4), Q04039.

Colbert, E. H. 1935. Siwalik mammals in the American Museum of Natural History.

Transactions of the American Philosophical Society, New Series, 26, 1-401.

Colbert, E. H. 1938. Fossil mammals from Burma in the American Museum of Natural History. Bulletin of the American Museum of Natural History, 74(6), 255-436.

Corbet, G. B. \& Hill, J. E. 1992. The Mammals of the Indomalayan Region: A Systematic Review. Oxford University Press, Oxford, 488 pp.

Cuenca Bescós, G. 1988. Revisiºn de los Sciuridae del Aragoniense y del Rambliense en la fosa de Calatayud-Montalb’́an. Scripta Geologica, 87, 1-116.

Denys, C., Sandrock, O., Kullmer, O., Rozzi, F. R., Bromage, T. G. \& Schrenk, F. 2011. Note on the presence of Hystrix (Mammalia, Rodentia) in the Malawi

Chiwondo Beds (PlioPleistocene): taphonomical and palaeoecological implications. Geodiversitas, 33, 729-738.

Egi, N., Thaung-Htike, Zin-Maung-Maung-Thein, MaungMaung, Nishioka, Y., Tsubamoto, T., Ogino, S. \& Takai, M. 2011. A mongoose remain (Mammalia: Carnivora) from the Upper Irrawaddy sediments, Myanmar and its significance in evolutionary history of Asian herpestids. Journal of Asian Earth Sciences, 42, 1204 1209.

Fischer von Waldheim, G. 1803. Das Nationalmuseum der Naturgeschichte zu Paris. Von seinem ersten Ursprunge bis zu seinem jetzigen Glanze geschildert von Gotthelf Fischer. Freidrich Esslinger, Frankfurt am Main, 425 pp.

Fischer von Waldheim, G. 1817. Adversaria zoologica.Mémoires de la Société impériale des naturalistes de Moscou, 5, 368-428.

Flynn, L. J. 1982. Systematic revision of Siwalik Rhizomyidae (Rodentia). Geobios, $15,327-389$.

Flynn, L. J. 1990. The natural history of rhizomyid rodents. Pp. 155-183 in E. Novo \& O. Reig (eds) Evolution of subterranean mammals at the organismal and molecular levels. Wiley-Liss, New York. 
Freudenthal, M. \& Suárez, M. E. 1999. Family Muridae. Pp. 401-409 in G. E. Rössner \& K. Heissig (eds) Land mammals of Europe. Verlag Dr. Friedrich Pfeil, München.

Ginsburg, L., Ingavat, R. \& Sen, S. 1982. A middle Pleistocene(Loangian) cave fauna in northern Thailand. Comptes Rendus de l'Académie des Sciences, Série 2, 19, 295297.

Gray, J. E. 1821. On the natural arrangement of vertebrose animals. London Medical Repository, 15, 296-310.

Gray, J. E. 1842. Description of some new genera and fifty unrecorded species of Mammalia. Annals and Magazine of Natural History, 10, 255-267.

Gray, J. E. 1847. On the porcupines of the older or eastern continent. Proceedings of the Zoological Society of London, 15, 97-104.

Gray, J. E. 1866. On the species of porcupine in the gardens of the Society and in the British Museum. Proceedings of the Zoological Society of London, 1866, 306-311.

Greenwood, M. 1955. Fossil Hystricoidea from the Makapan Valley, Transvaal. Palaeontologia Africana, 3, 77-85.

Gyldenstolpe, N. C. G. F. 1917. Zoological results of the Swedish Zoological expeditions to Siam. V Mammals II. Kungliga Svenska Vetenskaps-Akademiens Handlingar, 57(2), 1-59.

Hallet, B. \& Molnar, P. 2001. Distorted drainage basins as markers of crustal strain east of the Himalaya. Journal of Geophysical Research, 106(B7), 13697-13709.

Hodgson, B. 1841. New species of Rhizomys discovered in Nepal. Calcutta Journal of Natural History, 2, 60-62.

Hodgson, B. 1847. On a new species of porcupine. Journal of the Asiatic Society of Bengal, 16, 771-774.

Hutchinson, C. S. 1989. Geological evolution of South-East Asia. Clarendon Press, Oxford, $368 \mathrm{pp}$.

Illiger, C. D. 1811. Prodromus systematis mammalium et aviumadditis terminis zoographicis uttriusque classis. Salfeld, Berlin, 301 pp. 
Jánossy, D. 1972. Ein kleiner Hystrix aus dem Altpleistozän der Fundstelle Osztramos 8 (Nordungarn). Vertebrata Hungarica, 13, 163-182.

Jacobs, L. L. 1978. Fossil rodents (Rhizomyidae \& Muridae) from Neogene Siwalik deposits, Pakistan. Museum of Northern Arizona Press, Bulletin Series, 52, 1-103.

Jacobs, L. L. \& Downs, W. R. 1994. The evolution of murine rodents in Asia. National Science Museum Monographs, 8, 149-156.

Jentink, F. A. 1910. On a new mouse from Java. Notes from the Leyden Museum, 33(1), 9-232.

Jin, C.-Z., Kawamura, Y. \& Taruno, H. 1999. Pliocene andEarly Pleistocene insectivore and rodent faunas from Dajushan, Qipanshan and Haimao in North China and the reconstruction of the faunal succession from the Late Miocene to Middle Pleistocene. Journal of Geosciences, Osaka City University, 42(1), 1-19.

Jin, C.-Z., Qin, D.-G., Pan, W.-S., Tang, Z.-L., Liu, J.-Y., Wang, Y., Deng, C.-L., Zhang, Y.-Q., Dong, W. \& Tong,H.-W. 2009. A newly discovered Gigantopithecus fauna from Sanhe Cave, Chongzuo, Guangxi, South China. Chinese Science Bulletin, 54, 788-797.

Kawamura, Y. 1988. Quaternary rodent faunas in the Japanese Islands (Part 1). Memoirs of the Faculty of Science, Kyoto University, Series of Geology \& Mineralogy, 53(1 \& 2), 31-348.

Lacomba Andueza, J. I. 1988. Rodents and lagomorphs from aLower Vallesian fissure filling near Molina de Aragón (Prov. de Guadalajara, Spain). Scripta Geologica Special Issue, 1, 19-38.

Linnaeus, C. 1758. Systema naturae per regna tria naturae, secundumclasses, ordines, genera, species cum characteribus, differentiis, synonymis, locis.

Laurentii Salvii, Stockholm, 824 pp.

Lucas, S. G. 2001. Chinese Fossil Vertebrates. Columbia University Press, New York, $375 \mathrm{pp}$.

Lunde, D. P. \& Aplin, K. P. 2008. Hapalomys delacouri.IUCN Red List of Threatened Species. Version 2012. 2. Updated at: http://www.iucnredlist.org, 
accessed 4 January 2013.

Lunde, D. P., Aplin, K. P. \& Molur, S. 2008. Hystrix brachyura. IUCN Red List of Threatened Species. Version 2012. 2. Updated at: http://www.iucnredlist.org, accessed 4 January 2013.

Lydekker, R. 1878. Notices of Siwalik mammals. Records of the Geological Survey of India, 11(1), 64-104.

Marsden, W. 1811. The History of Sumatra. W. Marsden, London, 479 pp.

Marshall, J. 1871. A note. P. 235 in F. R. S. Flower (ed.) Notes on rare or little-known animals now or lately living in the society's gardens. Zoological Society of London, London.

McKenna, M. C. \& Bell, S. K. 1997. Classification of mammals above the species level. Columbia University Press, New York, 631 pp.

Meijaard, E. \& Groves, C. P. 2006. The geography of mammals and rivers in mainland Southeast Asia. Pp. 305-329 in S. M. Lehman \& J. G. Fleagle (eds) Primate Biogeography. Springer, New York.

Miller, G. S. 1912. Catalogue of the mammals of western Europe: (Europe exclusive of Russia) in the collection of the British Museum. British Museum (Natural History), London, 1019 pp.

Moe-Nyunt. 1987. Geology and vertebrate fossils of Gwebin area, Seikpyu Township. Unpublished MSc thesis, Department of Geology, University of Yangon (Rangoon), Yangon, 253 pp.

Musser, G. G. 1972. The species of Hapalomys (Rodentia, Muridae). American Museum Novitates, 2503, 1-27.

Musser, G. G. 1981a. A new genus of arboreal rat from WestJava, Indonesia. Zoologische Verhandelingen uitgegeven door het Rijksmuseum van Natuurlijke Historie te Leiden, 189, 1-35.

Musser, G. G. 1981b. Results of the Archbold Expeditions. No. 105. Notes on systematics of Indo-Malayan murid rodents, and descriptions of new genera and species from Ceylon, Sulawesi, and the Philippines. Bulletin of the American 
Museum of Natural History, 168(3), 225-334.

Musser, G. G., Marshall, J. T., Jr. \& Boeadi 1979. Definitionand contents of the Sundaic genus Maxomys (Rodentia, Muridae). Journal of Mammalogy, 60, 592-606.

Musser, G. G. \& Newcomb, C. 1983. Malaysian murids and the giant rat of Sumatra. Bulletin American Museum of Natural History, 174(4), 327-598.

Naish, T. R. \& Wilson, G. S. 2009. Constraints on the amplitude of Mid-Pliocene (3.6-2.4 Ma) eustatic sea-level fluctuations from the New Zealand shallow-marine sediment record. Philosophical Transactions of the Royal Society, Series A, 367, 169-187.

Nishioka, Y., Zin-Maung-Maung-Thein, Egi, N., Tsubamoto,T., Nishimura, T., Ito, T., Thaung-Htike \& Takai, M. 2011. New Hystrix (Mammalia, Rodentia) from the late Miocene/early Pliocene of Myanmar. Journal of Vertebrate Paleontology, 31, 919-924.

Patnaik, R. 1997. New murids and gerbillids (Rodentia, Mammalia) from Pliocene Siwalik sediments of India. Palaeovertebrata, 26, 129-165.

Patnaik, R. 2001. Late Pliocene micromammals from Tatrot Formation (Upper Siwaliks) exposed near village Saketi, Himachal Pradesh, India. Palaeontographica Abteilung A, 261, 55-81.

Patnaik, R. 2003. Reconstruction of Upper Siwalik palaeoecology and palaeoclimatology using microfossil palaeocommunities. Palaeogeography, Palaeoclimatology, Palaeoecology, 197, 133-150.

Patnaik, R. 2013. Indian Neogene Siwalik mammalian biostratigraphy: An overview. Pp. 423-444 in X.-M. Wang, L. J. Flynn \& M. Fortelius (eds) Fossil mammals of Asia: Neogene biostratigraphy and chronology. Columbia University Press, New York.

Patnaik, R. \& Nanda, A. C. 2010. Early Pleistocene mammalian faunas of India and evidence of connections with other parts of the world. Pp. 129-143 in H. G. Fleagle, J. J. Shea, F. L. Grine, A. L. Baden \& R. E. Leakey (eds) Out of Africa I. The first hominin colonization of Eurasia. Springer, New York. 
Patnaik, R., Badam, G. L., \& Murty, M. L. K. 2008. Additional vertebrate remains from one of the Late PleistoceneHolocene Kurnool Caves (Muchchatla Chintamanu Gavi) of South India. Quaternary International, 192,43-51.

Pickford, M. 1988. Revision of the Miocene Suidae of the Indian Subcontinent. Münchner Geowissenschaftliche Abhandlungen, Reihe A: Geologie und Paläontologie, 12, 1-92.

Qi, G.-Q. \& Ni, X.-J. 2006. Geological age of Lufengpithecus hudienensis. Pp. 229238 in G.-Q. Qi \& W. Dong (eds) Lufengpithecus hudienensis site. Science Press, Beijing. [in Chinese with English summary].

Rössner, G. E. 2007. Family Tragulidae. Pp. 213-220 in D. R. Prothero \& E. F. Scott (eds) The evolution of artiodactyls. The John Hopkins University Press, Baltimore. Ruedas, L. A. \& Kirsch, J. A. 1997. Systematics of Maxomys Sody, 1936 (Rodentia: Muridae: Murinae): DNA/DNA hybridization studies of some Borneo-Javan species and allied Sundaic and Australo-Papuan genera. Biological Journal of the Linnean Society, 61, 385-408.

Sen, S. 1999. Family Hystricidae. Pp. 427-434 in G. E. R€ossner \& K. Heissig (eds) The Miocene land mammals of Europe. Verlag Dr. Friedrich Pfeil, Munich.

Sen, S. 2001a. Early Pliocene porcupine (Mammalia, Rodentia) from Perpignan, France: a new systematic study. Geodiversitas, 23, 303-312.

Sen, S. 2001b. Rodents and insectivores from the Upper Miocene of Molayan, Afghanistan. Palaeontology, 44, 913-932.

Sen, S. \& Purabrishemi, Z. 2010. First porcupine fossils (Mammalia, Rodentia) from the late Miocene of NW Iran, with notes on late Miocene-Pliocene dispersal of porcupines. Paläontologische Zeitschrift, 84, 239-248.

Slaughter, B. H. \& James, G. T. 1979. Saidomys natrunensis, an arvicanthine rodent from the Pliocene of Egypt. Journal of Mammalogy, 60, 421-425.

Sody, H. 1936. Seventeen new generic specific, and subspecificnames for Dutch East Indian mammals. Natuurhmdig Tijdschrift voor Nederlandsch-Indië, 96, 42-55.

Stamp, L. D. 1922. An outline of the Tertiary geology of Burma. 
Geological Magazine, 59, 481-501.

Storch, G. \& Ni, X.-J. 2002. New Late Miocene murids from China (Mammalia, Rodentia). Geobios, 35, 515-521.

Swinhoe, R. 1871. Catalogue of the mammals of China. Proceedings of the Zoological Society of London, 1870, 615-653.

Takai, M., Saegusa, H., Thaung-Htike \& Zin-Maung-MaungThein 2006. Neogene mammalian fauna in Myanmar. Asian Paleoprimatology, 4, 143-172.

Teilhard de Chardin, P. 1942. New rodents of the Pliocene andLower Pleistocene of North China. Institut de Ge'o-Biologie, 9, 1-101.

Thaung-Htike, Tsubamoto, T., Takai, M., Egi, N., Chit-Sein,Maung-Maung \& Zin-Maung-Maung-Thein 2006. Discovery of Propotamochoerus (Artiodactyla, Suidae) from the Neogene of Myanmar. Asian Paleoprimatology, 4, 173-185.

Thomas, O. 1908. On the generic position of the groups of squirrels typified by "Sciurus" berdmorei and pernyi, respectively, with descriptions of some new oriental species. Journal of Bombay Natural History Society, 18, 244-249.

Thomas, O. 1915. VII.-Notes on the Asiatic Bamboo-Rats (Rhizoyms, etc.). Annals and Magazine of Natural History, Series 8, 16, 56-61.

Thomas, O. 1916. VI.-The porcupine of Tenasserim and Southern Siam. Annals and Magazine of Natural History, Series 8, 17, 136-139.

Thomas, O. 1922. Scientific results of the mammal survey. No. XXXII. New and interesting mammals from the Mishmi Hills. Journal of the Bombay Natural History Society, 28, 428-432.

Tong, H.-W. 2008. Quaternary Hystrix (Rodentia, Mammalia) from North China: taxonomy, stratigraphy and zoogeography, with discussions on the distribution of Hystrix in Palearctic Eurasia. Quaternary International, 179, 126-134.

Tsubamoto, T., Thaung-Htike, Zin-Maung-Maung-Thein, Egi, N., Nishioka, Y., Maung-Maung \& Takai, M. 2012. New data on the Neogene anthracotheres (Mammalia, Artiodactyla) from central Myanmar. Journal of Vertebrate 
Paleontology, 32, 956-964.

Verneau, O., Catzeflis, F. \& Furano, A. V. 1997. Determination of the evolutionary relationships in Rattus sensu lato (Rodentia: Muridae) using L1 (LINE-1) amplification events. Journal of Molecular Evolution, 45, 424-436.

Voris, H. K. 2000. Maps of Pleistocene sea levels in Southeast Asia: shorelines, river systems and time durations. Journal of Biogeography, 27, 1153-1167.

Wang, B.-Y. \& Qi, G. Q. 2005. A porcupine (Rodentia, Mammalia) from Lufengpithecus site, Lufeng, Yunnan. Vertebrata PalAsiatica, 43, 11-23. [in Chinese with English summary].

Wang, B.-Y. \& Qiu, Z.-X. 2002. A porcupine from Late Miocene of Linxia Basin, Gansu, China. Vertebrata PalAsiatica, 40, 23-33. [in Chinese with English summary].

Weers, D. J. V. 2003. The porcupine Hystrix (Acanthion) brachyura punungensis subsp. nov. from late Pleistocene fissure deposits near Punung, Java. Scripta Geologica, 126, 217-225.

Weers, D. J. V. 2005. A taxonomic revision of the Pleistocene Hystrix (Hystricidae, Rodentia) from Eurasia with notes on the evolution of the family. Contributions to Zoology, 74, 301-312.

Weers, D. J. V. \& Rook, L. 2003. Turolian and Ruscinian porcupines (genus Hystrix, Rodentia) from Europe, Asia and North Africa. Pala€ontologische Zeitschrift, 77, 95113.

Zhang, Q., Zheng, Z.-G., Sun, L.-F. \& Song, Y.-L. 2009. Theorigin and phylogenetics of Hainan Eld's deer and implications for Eld's deer conservation. Acta Theriologica Sinica, 29, 365-371. [in Chinese with English summary].

Zheng, S.-H. 1993. Quaternary rodents of Sichuan-Guizhou area, China. Science Press, Beijing, 270 pp. [in Chinese with English summary].

Zin-Maung-Maung-Thein, Takai, M., Tsubamoto, T., Thaung-Htike, Egi, N. \& Maung-Maung 2008. A new species of Dicerorhinus (Rhinocerotidae) from the Plio-Pleistocene of Myanmar. Palaeontology, 51, 1419-1433. 
Zin-Maung-Maung-Thein, Takai, M., Uno, H., Wynn, J. G.,Egi, N., Tsubamoto, T., Thaung-Htike, Aung-Naing-Soe, Maung-Maung, Nishimura, T. \& Yoneda, M. 2011. Stable isotope analysis of the tooth enamel of Chaingzauk mammalian fauna (late Neogene, Myanmar) and its implication to paleoenvironment and paleogeography. Palaeogeography, Palaeoclimatology, Palaeoecology, 300, 11-22. 


\section{Captions}

Figure 1. Topographical map of the Gwebin area in Seikpyu Township with fossil localities: 1, Gbn1; 2, Mg1/2; 3, Gbn2; 4, Gbn3; 5,Gbn4; 6, Gbn5; 7, Gbn6; 8, GbnF1; 9, TBG1; 10, TBG2; 11, TBG3; 12, TBG4; 13, TBG5; 14, Psw 1; 15, Psw2. Broken lines on the topographical map are contour lines.

Figure 2. Columnar section of the Irrawaddy sediments at three fossil localities in the Gwebin area and fossil-bearing horizons.

Figure 3. Terminology and measuring points of occlusal surfaces of left teeth. A and B are modified after Musser (1981b). A, upper molar row of Muridae; B, lower molar row of Muridae; C, upper cheek tooth of Hystricidae; D, lower cheek tooth of Hystricidae; E, upper molar of Spalacidae; F, lower molar of Spalacidae; G, $\mathrm{P}_{4}$ of Sciuridae; H, lower molar of Sciuridae. Abbreviations: a-cen, anterocentral cusp; al, anteroloph; a-lab, anterolabial cusp; alc, anterior labial cusplet; ald, anterolophid; aling, anterolingual cusp; cusps t1 tot9, main cusps on murid upper molars; ed, entoconid; hd, hypoconid; hyl, hypoloph; hyld, hypolophid; L, anteroposterior length of crown; md, metaconid; msd, mesoconid; msl, mesoloph; msld, mesolophid; mssd, mesostylid; mtl, metaloph; mtld, metalophid; pc, posterior cingulum; pd, protoconid; pl, posteroloph; plc, posterior labial cusplet; pld, posterolophid; prl, protoloph; tab, talonid basin; W, labiolingual width of crown.

Figure 4. Schematic drawings of the molar occlusal surfaces of Hapalomys cf. longicaudatus from Gwebin. A, IR 2543, right $\mathrm{M}^{1}$; B, IR 1966, left M$^{1}$; C, IR 2542, left $\mathrm{M}^{1}$; D, IR 2541, left $\mathrm{M}^{1}$; E, IR 1955, right $\mathrm{M}_{1}-\mathrm{M}_{3} ; \mathrm{F}$, IR 2524, right $\mathrm{M}_{1}$; G, IR 2105, right $\mathrm{M}_{2} ; \mathrm{H}, \mathrm{IR} 2545$, right $\mathrm{M}_{2}$; I, IR1965, left $\mathrm{M}_{2}-\mathrm{M}_{3} ; \mathrm{J}$, IR 1967, left $\mathrm{M}_{2} ; \mathrm{K}$, IR 2544, left $\mathrm{M}_{2}$; L, IR 2523, left $\mathrm{M}_{2}$.

Figure 5. Comparison of maxillae or $\mathrm{M}^{1}$ amongst four murid species from Gwebin. A, 
Hapalomys cf. longicaudatus, IR 1966, left maxilla with $\mathrm{M}^{1}$; A1, labial view; A2, occlusal view; A3, lingual view. B, Maxomys pliosurifer sp. nov., IR 1995, right maxilla with $\mathrm{M}^{1}-\mathrm{M}^{3}$; $\mathrm{B}$ 1, labial view; $\mathrm{B} 2$, occlusal view; $\mathrm{B} 3$, lingual view. C, Rattus jaegeri, IR 2108, left $\mathrm{M}^{1}$; C1, labial view; C2, occlusal view; C3, lingual view. D, cf. Rattus sp. indet., IR 2551, left maxilla with $\mathrm{M}^{1}-\mathrm{M}^{3}$; D1, labial view; D2, occlusal view; D3, lingual view.

Figure 6. Comparison of mandibles amongst four murid species from Gwebin. A, Hapalomys cf. longicaudatus, IR 1955, right mandible with $\mathrm{M}_{1}-\mathrm{M}_{3}$; $\mathrm{A} 1$, lingual view; A2, labial view. B, Maxomys pliosurifer sp. nov., IR 2067, left mandible with $\mathrm{M}_{1}-\mathrm{M}_{3}$; B1, lingual view; B2, labial view. C, Rattus jaegeri, IR 1929, left mandible with $\mathrm{M}_{1-}$ $\mathrm{M}_{3}$; C1, lingual view; C2, labial view. D, cf. Rattus sp. indet., IR 1964, left mandible with $\mathrm{M}_{1}-\mathrm{M}_{3}$; D1, lingual view; D2, labial view.

Figure 7. Bivariate plot of width against length of $\mathrm{M}^{1}$ and $\mathrm{M}_{2}$ amongst six species of Hapalomys (Zheng 1993; Chaimanee 1998; this study).

Figure 8. Schematic drawings of molar ocelusal surfaces from Gwebin. A-G, Maxomys pliosurifer sp. nov.; A, IR 1995, right $\mathrm{M}^{1}-\mathrm{M}^{3}$; B, IR 2552, left $\mathrm{M}^{1}$; C, IR 2553, right $\mathrm{M}^{2}$; D, IR 2554, left $\mathrm{M}^{2}$; E, IR 2067, left $\mathrm{M}_{1}-\mathrm{M}_{3}$; F, IR 2057, right $\mathrm{M}_{1}$; G, IR 2556, left $\mathrm{M}_{1}$. H-M, Rattus jaegeri; H, IR 2108, right $\mathrm{M}^{1}$; I, IR 2106, left $\mathrm{M}^{1}$; J, IR 2548, left $\mathrm{M}^{1} ; \mathrm{K}$, IR 2832, left $\mathrm{M}^{1}$; L, IR 2555, right $\mathrm{M}^{2}$; M, IR 1929, left $\mathrm{M}_{1-}$ $\mathrm{M}_{3}$. N-T, cf. Rattus sp. indet.; N, IR 2551, left $\mathrm{M}^{1}-\mathrm{M}^{3}$; O, IR 2833, left $\mathrm{M}^{2}$; P, IR 1964, left $\mathrm{M}_{1}-\mathrm{M}_{3} ; \mathrm{Q}, \mathrm{M} 1-178$, right $\mathrm{M}_{2}-\mathrm{M}_{3} ; \mathrm{R}$, IR 2056, right $\mathrm{M}_{2}-\mathrm{M}_{3} ; \mathrm{S}$, IR 2104, left $\mathrm{M}_{2}-\mathrm{M}_{3} ; \mathrm{T}$, IR 2834, right $\mathrm{M}_{3}$.

Figure 9. Schematic drawings of molar occlusal surfaces from Gwebin. A-C, Hystrix paukensis; A, M1-108, left $\mathrm{M}_{1 / 2}$; B, IR 1620, right $\mathrm{M}_{3}$; C, IR 1959, right $\mathrm{M}_{3}$. D-L, $H$. sp. indet. (brachydont form); D, IR 2058, left $\mathrm{P}^{4}$; E, IR 1957, right $\mathrm{M}^{1 / 2}$; F, 
IR 1560, left $\mathrm{M}^{1 / 2} ; \mathrm{G}$, IR 1958, right $\mathrm{dP}_{4} ; \mathrm{H}$, IR 1927, left $\mathrm{P}_{4} ;$ I, M1-179-1, right $\mathrm{M}_{1 / 2}$; J, IR 2520, left $\mathrm{M}_{1 / 2} ; \mathrm{K}$, IR 1871, left $\mathrm{M}_{1 / 2}$; L, IR 2521, left $\mathrm{M}_{3}$. M, $H$. cf. brachyura M1-179-2, left $\mathrm{M}_{1 / 2}$.

Figure 10. Labial surface of left $\mathrm{M}_{1 / 2}$ in three species of Hystrix from Gwebin. A, $H$. paukensis, M1-108; B, H. sp. indet. (brachydont form), IR 2520; C, H. cf. brachyura, M1-179-2. Dotted lines show cervical.

Figure 11. Schematic drawings of the molar occlusal surfaces of Cannomys cf. badius from Gwebin. A, IR 2531, left $\mathrm{M}^{1}$; B, IR 2537, left $\mathrm{M}^{2}$; C, IR 2522, right $\mathrm{M}^{3}$; D, IR 1956, right $\mathrm{M}_{1}$; E, IR 2535, right $\mathrm{M}_{2} ; \mathrm{F}$, IR 2536, right $\mathrm{M}_{2} ; \mathrm{G}$, IR 2530, right $\mathrm{M}_{3} ; \mathrm{H}$, IR 2103, right $\mathrm{M}_{3}$; I, IR 2102, left $\mathrm{M}_{3}$.

Figure 12. Molar occlusal surfaces of Menetes sp. indet. from Gwebin. A, IR 2532, left $\mathrm{P}_{4}$; B, IR 2835, left $\mathrm{P}_{4}$; C, IR 2836, left $\mathrm{M}_{1}$; D, IR 2837, left $\mathrm{M}_{1}$; E, IR 2533, left $\mathrm{M}_{2} ; \mathrm{F}$, IR 2838, left $\mathrm{M}_{2} ; \mathrm{G}$, IR 2534, right $\mathrm{M}_{3}$.

Figure 13. Distribution of four genera of rodents in the Indochinese Division with their fossil records from the Late Pliocene/Early Pleistocene localities (IUCN Red List data; Chaimanee 1998; Tong 2008; Jin et al. 2009). A, Hapalomys; B, Hystrix; C, Maxomys; D, Cannomys. Rivers: 1, Yellow River; 2, Yangtze River; 3, Pearl River; 4, Red River; 5, Mekong River; 6, Salween River; 7, Irrawaddy River; 8, Brahmaputra River; 9, Ganges River.

Table 1. Fossil localities with GPS record in Gwebin area.

Table 2. List of fossil mammals from Gwebin area.

Table 3. Stratigraphical distribution of the rodent species found from Gwebin 
area. Solid circle, this study. Open circle, previous records (Chaimanee 1998;

Weers 2005; Nishioka et al. 2011). 


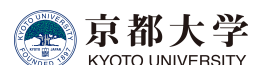

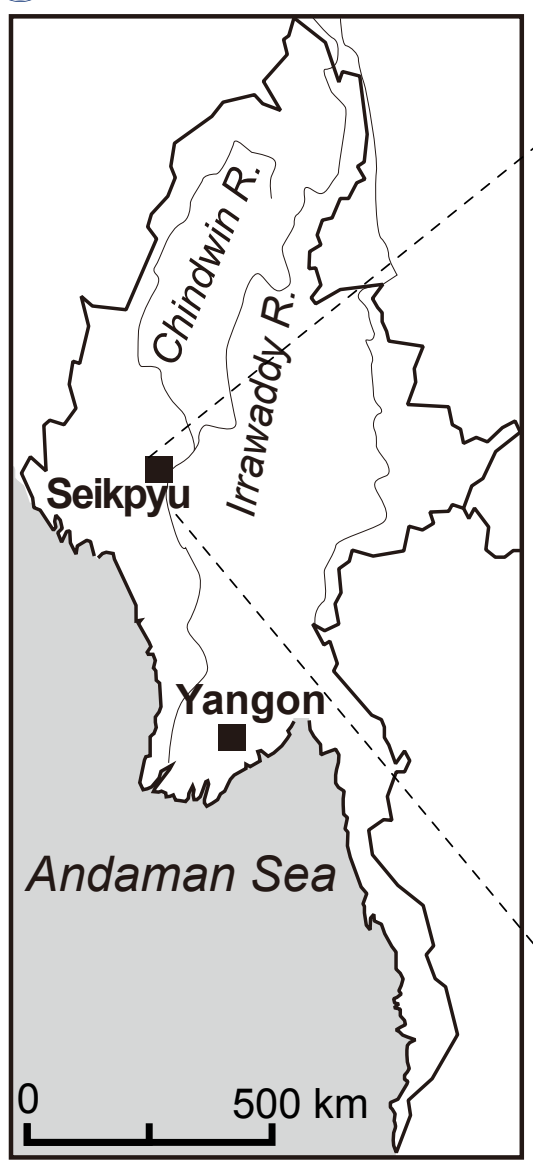

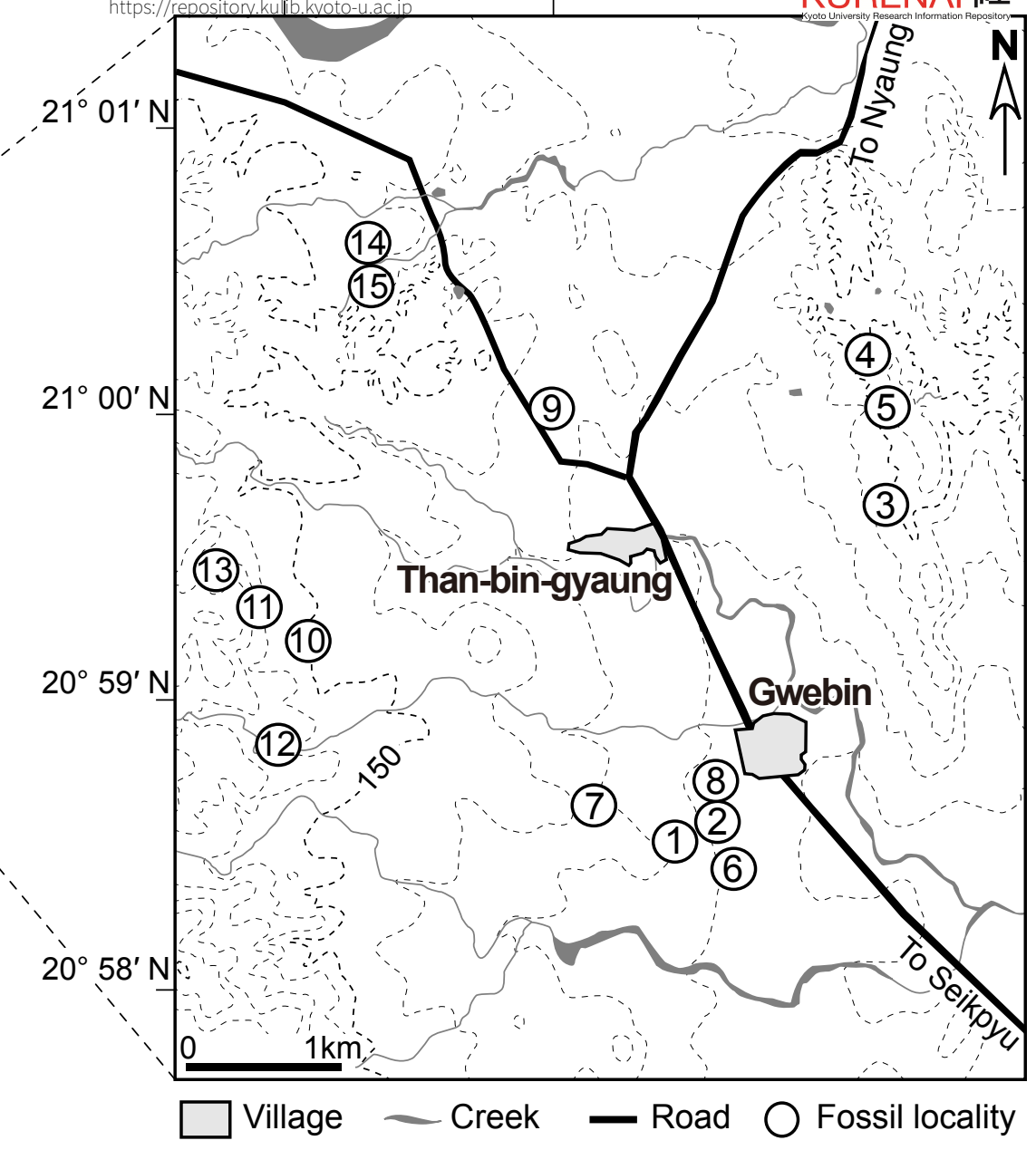

Figure1 
竞都大兴 A Self-archived copy in

KYOTO UNIVERSITY

osi 1
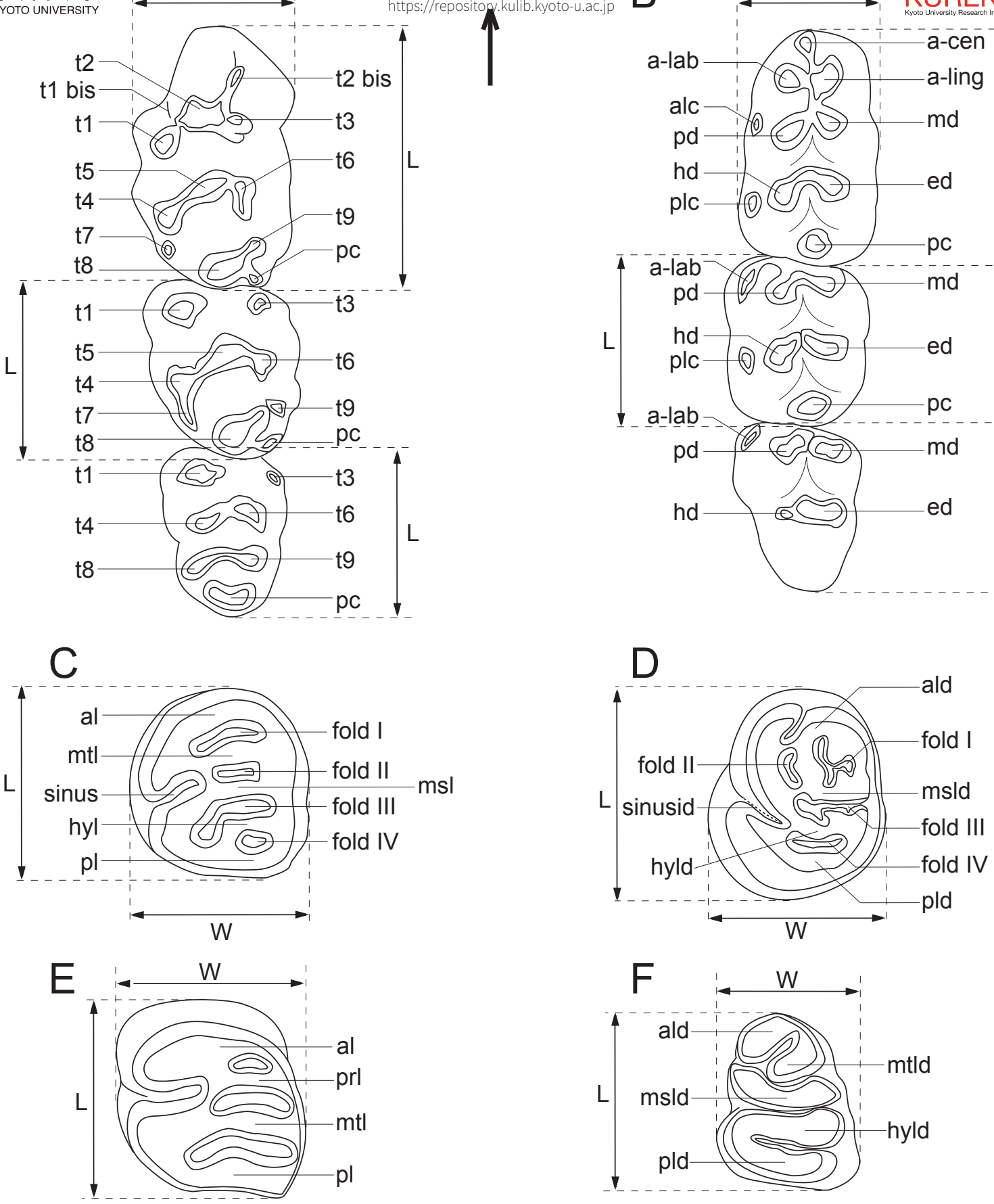

G pad

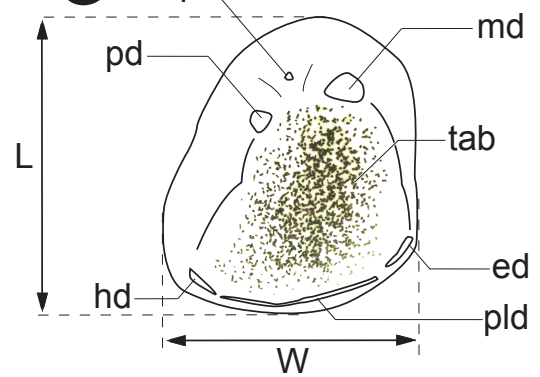

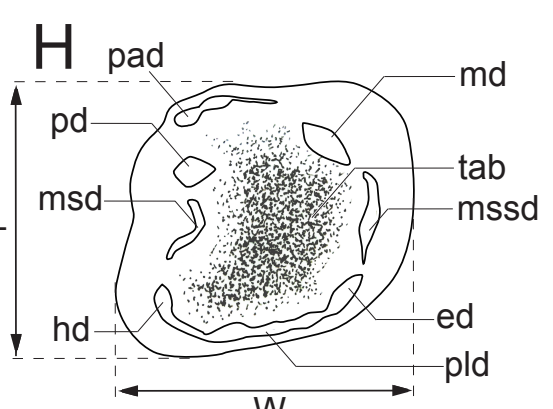


2. 京都大学

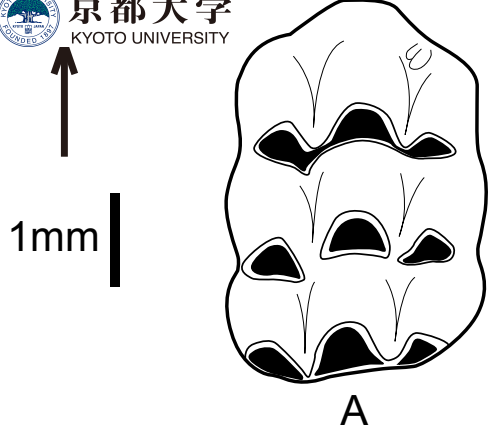

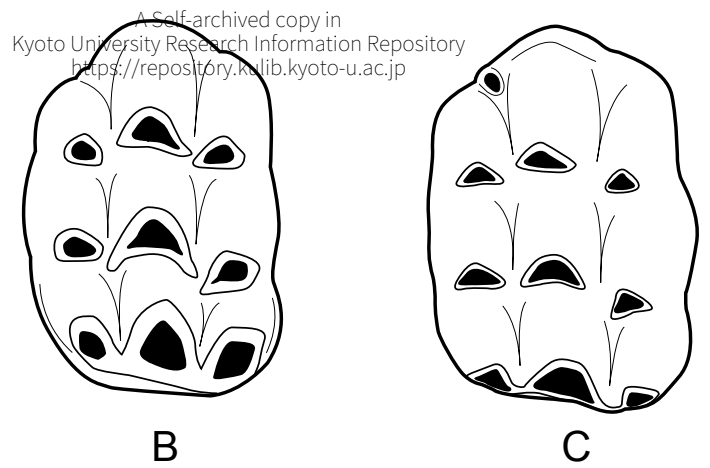
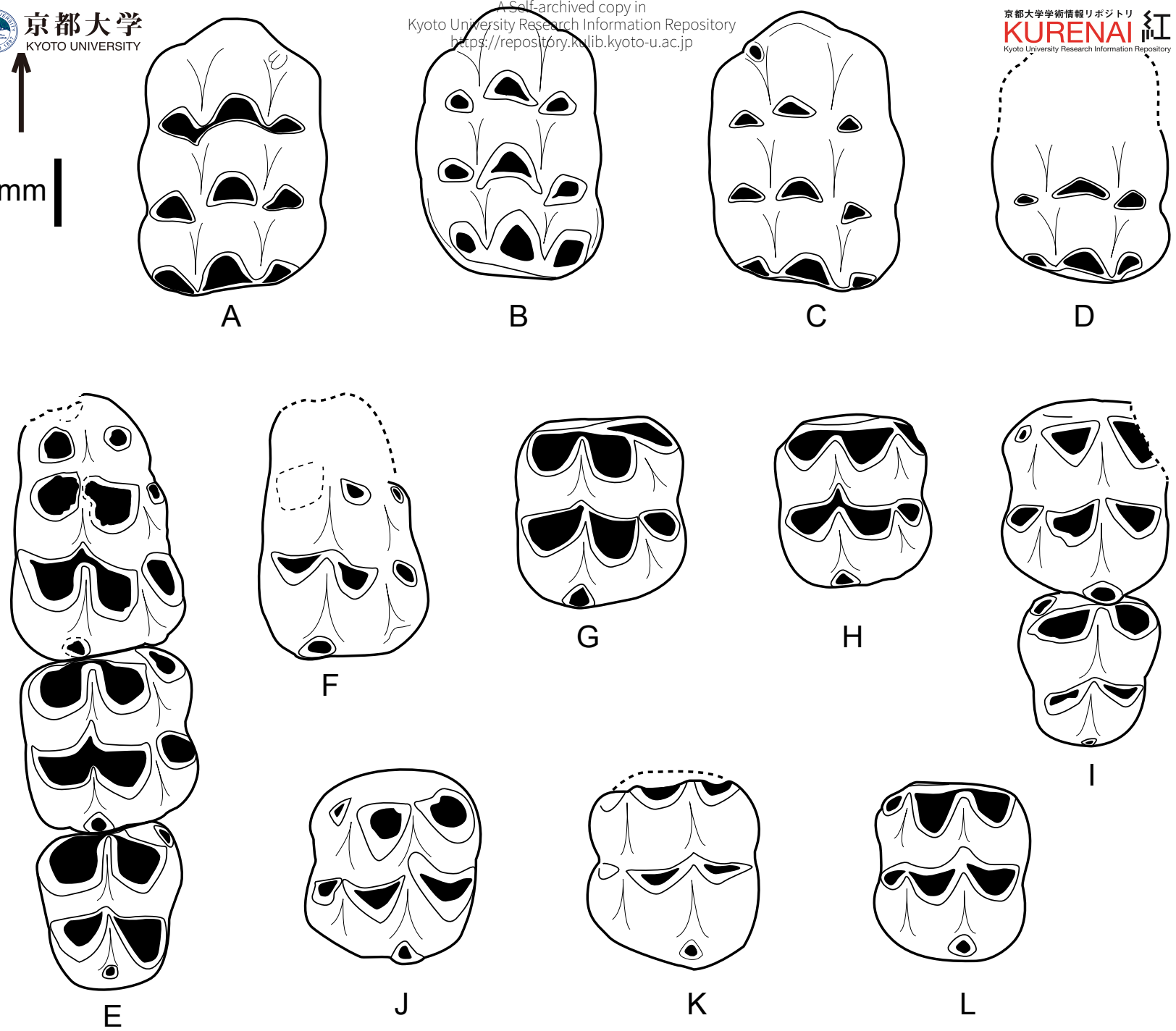

Figure4 
19. 京都大学

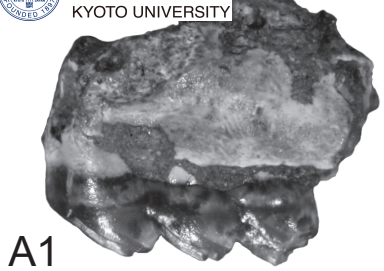

A1 W o
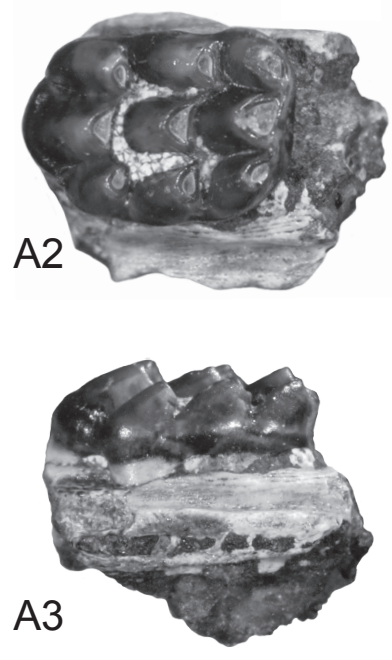

anterior $\longleftarrow \quad 1 \mathrm{~mm}$

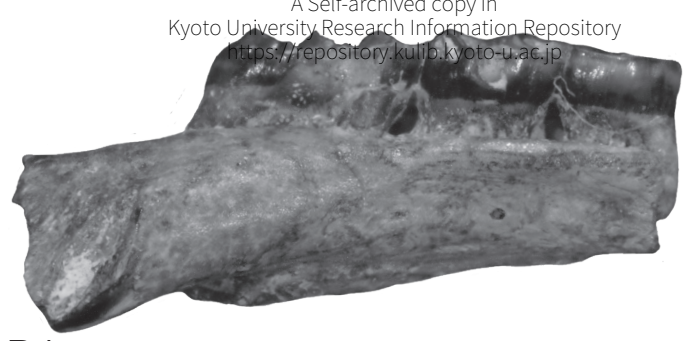

B1
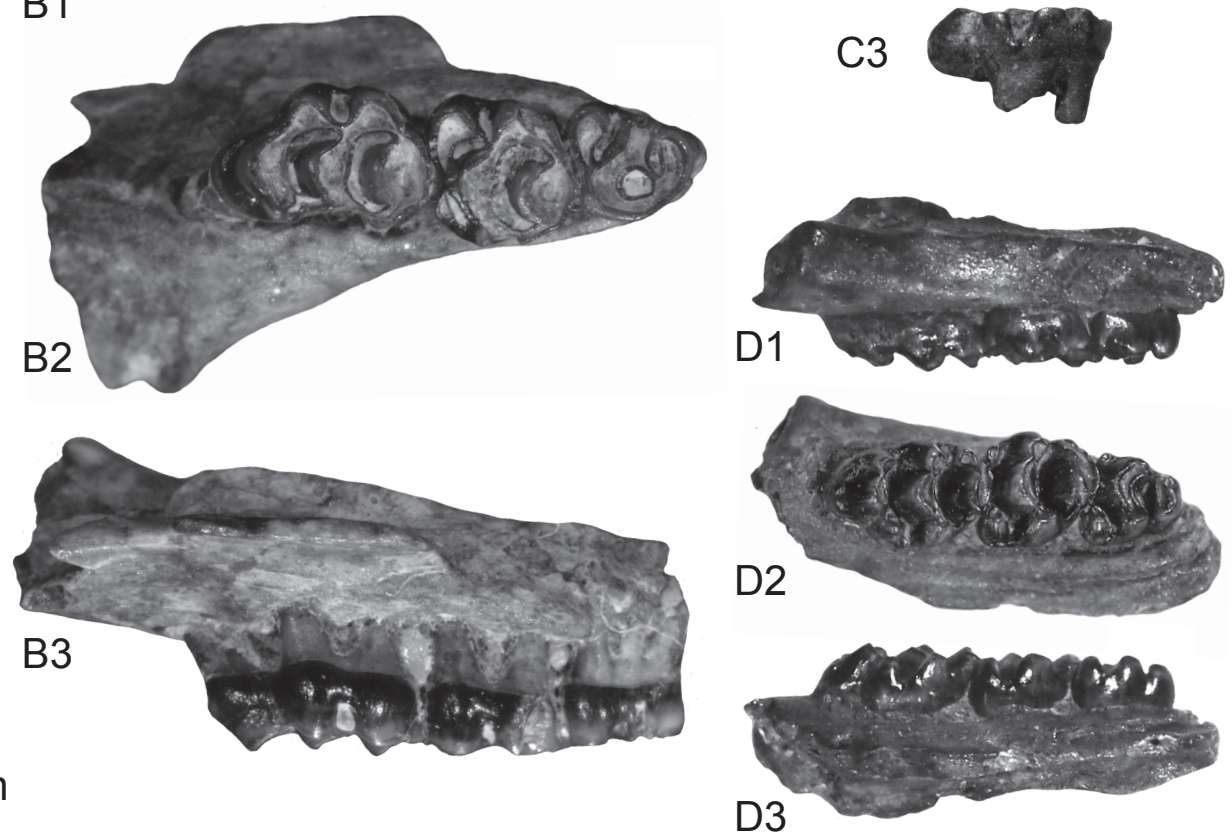

Figure5 


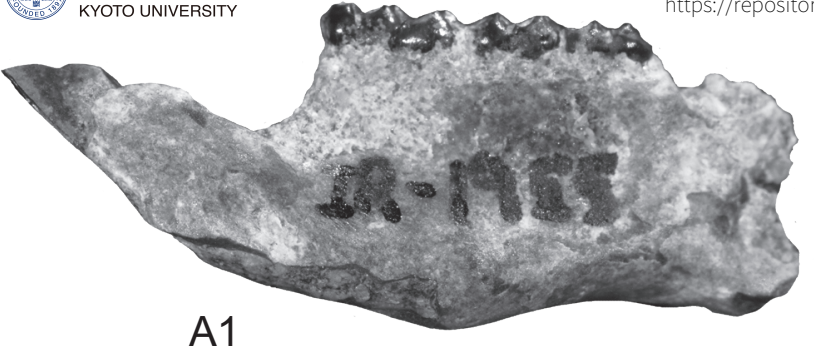

A1

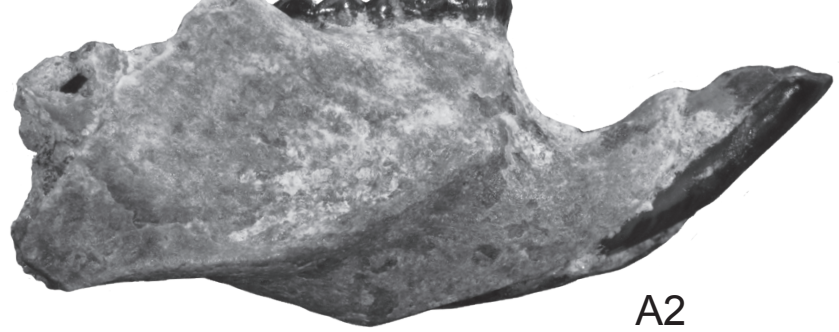

B1
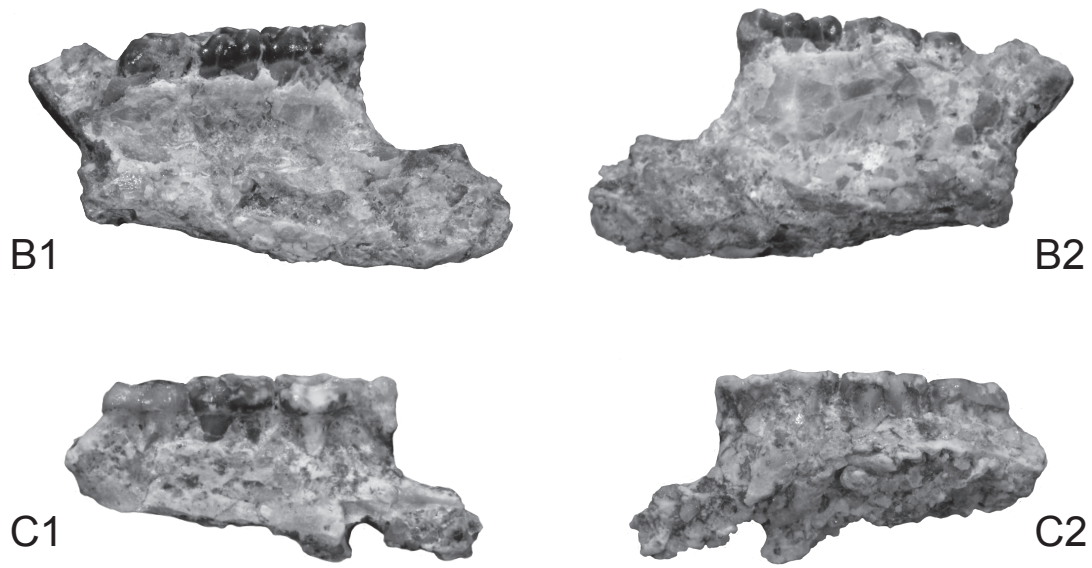

$1 \mathrm{~mm}$
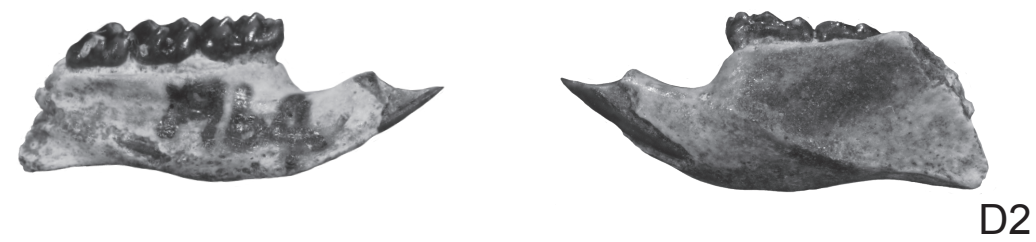

Figure6 


\section{京都大学}

KYOTO UNIVERSITY

Width

( $\mathrm{mm}$ )

${ }^{3.0} \mathbf{M}^{1}$ Length

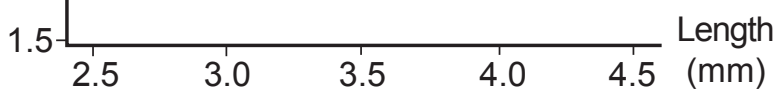

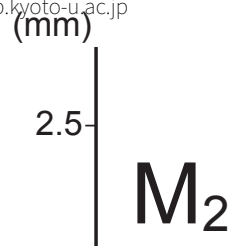

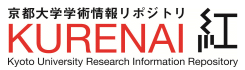

O

○

O

○

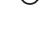

$\bigcirc \mathrm{H}$. cf. longicaudatus

$\square$ H. eurycidens

$\triangle H$. khaorupchangi

- $\mathrm{H}$. longicaudatus

Figure7 


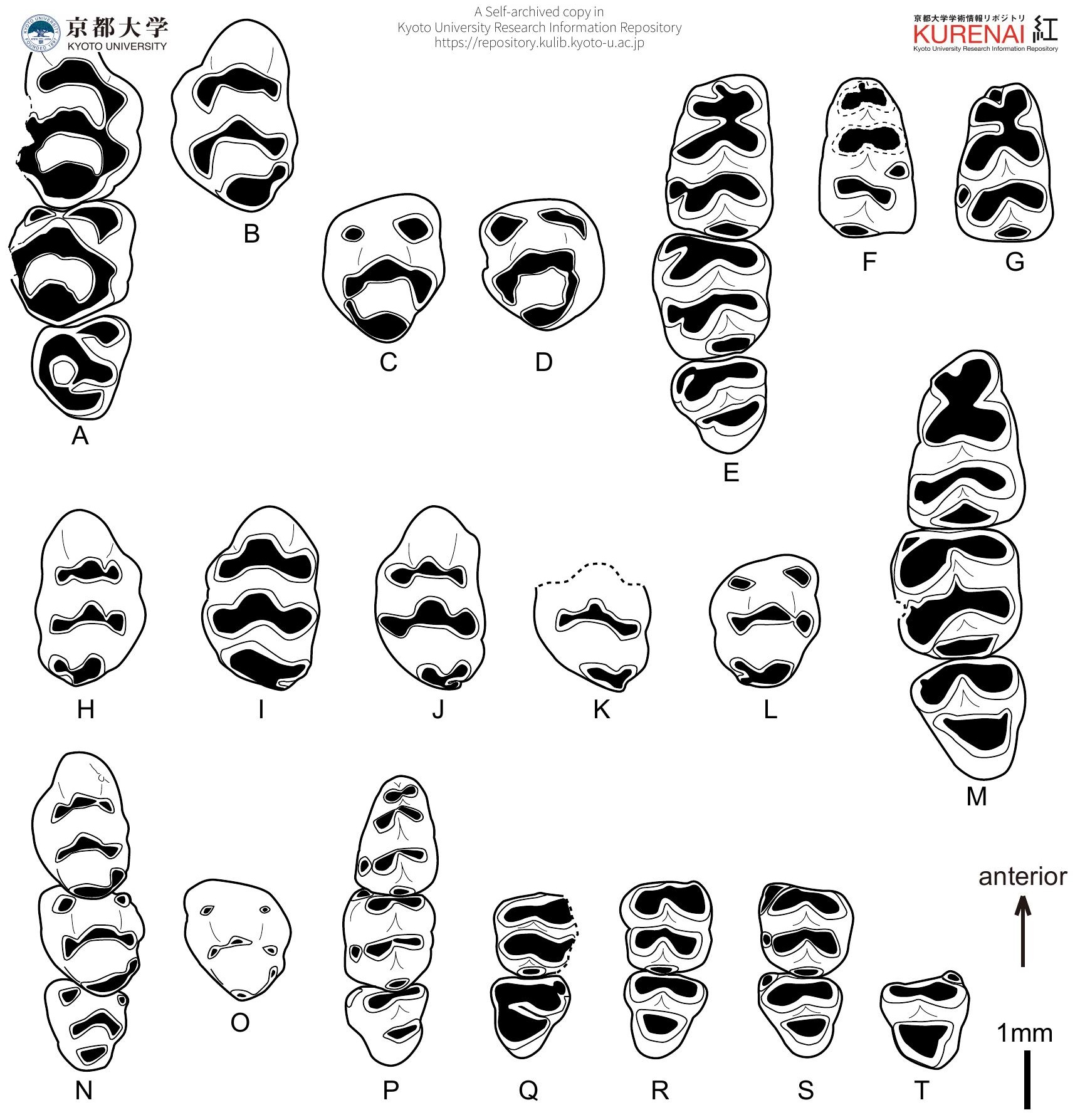

Figure8 


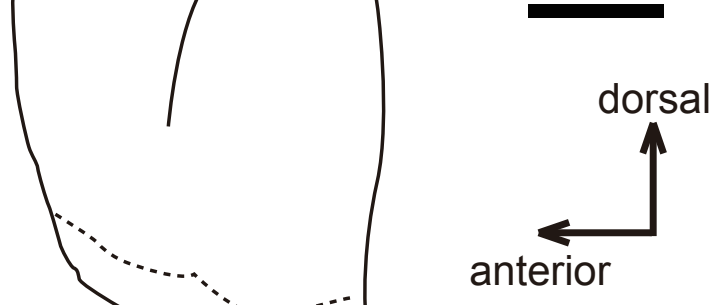

B
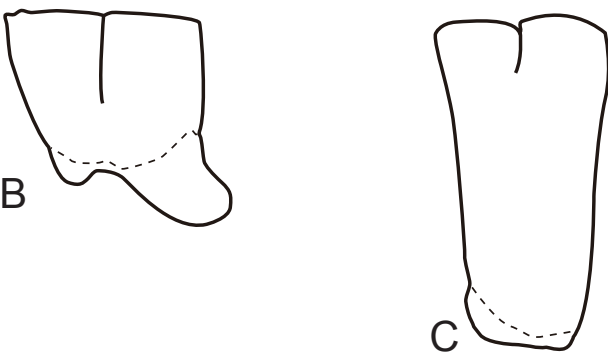

Figure10 


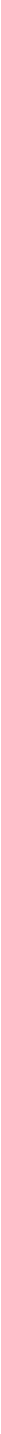

Figure13 
Table 1.

\begin{tabular}{lll}
\hline Locality & Latitude & Longitude \\
\hline Gbn1 & $20^{\circ} 58^{\prime} 13^{\prime \prime}-35^{\prime \prime} \mathrm{N}$ & $94^{\circ} 41^{\prime} 23^{\prime \prime}-36^{\prime \prime} \mathrm{E}$ \\
Mg1/2 & $20^{\circ} 58^{\prime} 33^{\prime \prime} \mathrm{N}$ & $94^{\circ} 41^{\prime} 36^{\prime \prime} \mathrm{E}$ \\
Gbn2 & $20^{\circ} 59^{\prime} 41^{\prime \prime}-51^{\prime \prime} \mathrm{N}$ & $94^{\circ} 42^{\prime} 11^{\prime \prime}-20^{\prime \prime} \mathrm{E}$ \\
Gbn 3 & $21^{\circ} 00^{\prime} 14^{\prime \prime} \mathrm{N}$ & $94^{\circ} 42^{\prime} 12^{\prime \prime} \mathrm{E}$ \\
Gbn 4 & $21^{\circ} 00^{\prime} 04^{\prime \prime} \mathrm{N}$ & $94^{\circ} 42^{\prime} 16^{\prime \prime} \mathrm{E}$ \\
Gbn5 & $20^{\circ} 58^{\prime} 25^{\prime \prime} \mathrm{N}$ & $94^{\circ} 41^{\prime} 40^{\prime \prime} \mathrm{E}$ \\
Gbn6 & $20^{\circ} 58^{\prime} 38^{\prime \prime} \mathrm{N}$ & $94^{\circ} 41^{\prime} 10^{\prime \prime} \mathrm{E}$ \\
GbnF1 & $20^{\circ} 58^{\prime} 42^{\prime \prime} \mathrm{N}$ & $94^{\circ} 41^{\prime} 35^{\prime \prime} \mathrm{E}$ \\
TBG1 & $20^{\circ} 59^{\prime} 58^{\prime \prime}-21^{\circ} 00^{\prime} 01^{\prime \prime} \mathrm{N}$ & $94^{\circ} 40^{\prime} 52^{\prime \prime}-54^{\prime \prime} \mathrm{E}$ \\
TBG2 & $20^{\circ} 59^{\prime} 10^{\prime \prime} \mathrm{N}$ & $94^{\circ} 40^{\prime} 04^{\prime \prime} \mathrm{E}$ \\
TBG3 & $20^{\circ} 59^{\prime} 14^{\prime \prime} \mathrm{N}$ & $94^{\circ} 39^{\prime} 55^{\prime \prime} \mathrm{E}$ \\
TBG4 & $20^{\circ} 58^{\prime} 51^{\prime \prime} \mathrm{N}$ & $94^{\circ} 40^{\prime} 00^{\prime \prime} \mathrm{E}$ \\
TBG5 & $20^{\circ} 59^{\prime} 24^{\prime \prime} \mathrm{N}$ & $94^{\circ} 39^{\prime} 43^{\prime \prime} \mathrm{E}$ \\
Psw1 & $21^{\circ} 00^{\prime} 35^{\prime \prime} \mathrm{N}$ & $94^{\circ} 40^{\prime} 17^{\prime \prime} \mathrm{E}$ \\
Psw2 & $21^{\circ} 00^{\prime} 29^{\prime \prime} \mathrm{N}$ & $94^{\circ} 40^{\prime} 21^{\prime \prime} \mathrm{E}$ \\
\hline
\end{tabular}


Table 2.

\begin{tabular}{|c|c|c|c|c|}
\hline & & $\mathrm{Gbn}^{*}$ & TBG & Psw \\
\hline Primate & Semnopithecus sp. indet. & $\bigcirc$ & $\bigcirc$ & $\bigcirc$ \\
\hline \multirow[t]{2}{*}{ Carnivora } & Urva sp. indet. & & $\bigcirc$ & \\
\hline & ?Hyaenidae gen. et sp. indet. & O & & \\
\hline \multirow[t]{9}{*}{ Rodentia } & Hapalomys cf. longicaudatus & $\bigcirc$ & & \\
\hline & Maxomys pliosurifer sp. nov. & $\bigcirc$ & & \\
\hline & Rattus jaegeri & $\bigcirc$ & & \\
\hline & Cf. Rattus sp. indet. & $\bigcirc$ & & $\bigcirc$ \\
\hline & Hystrix paukensis & $\bigcirc$ & $\bigcirc$ & \\
\hline & Hystrix sp. indet. (brachydont form) & $\bigcirc$ & & \\
\hline & Hystrix cf. brachyura & $\bigcirc$ & & \\
\hline & Cannomys cf. badius & $\bigcirc$ & & \\
\hline & Menetes sp. indet. & $\bigcirc$ & & \\
\hline Lagomorpha & Leporidae gen. et sp. indet. & $\bigcirc$ & & \\
\hline \multirow[t]{10}{*}{ Artiodactyla } & Merycopotamus dissimilis & $\bigcirc$ & $\bigcirc$ & \\
\hline & Microbunodon milaensis & $\bigcirc$ & $\bigcirc$ & \\
\hline & Sivaportax dolabella & $\bigcirc$ & $\bigcirc$ & $\bigcirc$ \\
\hline & Proleptobos birmanicus & $\bigcirc$ & $\bigcirc$ & $\bigcirc$ \\
\hline & Bovidae gen. et sp. indet. (large form) & $\bigcirc$ & $\bigcirc$ & \\
\hline & Hexaprotodon cf. iravaticus & & $\bigcirc$ & \\
\hline & Hexaprotodon sivalensis & $\bigcirc$ & $\bigcirc$ & \\
\hline & Hexaprotodon palaeindicus & & $\bigcirc$ & \\
\hline & Cf. Sus sp. indet. & $\bigcirc$ & $\bigcirc$ & $\bigcirc$ \\
\hline & Dorcabune sp. indet. & $\bigcirc$ & & \\
\hline \multirow[t]{3}{*}{ Perissodactyla } & Chalicotheriidae gen. et sp. indet. & $\bigcirc$ & & \\
\hline & Dicerorhinus gwebinensis & $?$ & & \\
\hline & Rhinoceros sp. indet. & $\bigcirc$ & $\bigcirc$ & \\
\hline Proboscidea & Stegodon sp. indet. & $\bigcirc$ & $\bigcirc$ & \\
\hline
\end{tabular}

* including Mg1/2, Gbn5 and GbnF1. 
Table 3.

\begin{tabular}{|c|c|c|c|c|c|c|c|c|c|}
\hline & 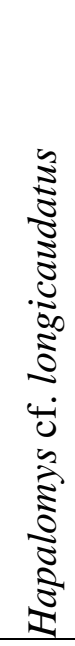 & 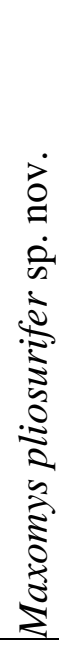 & 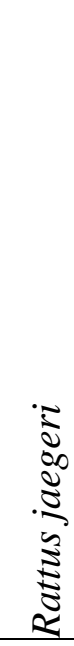 & 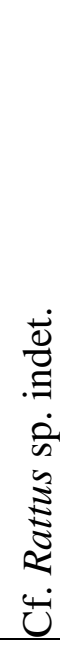 & 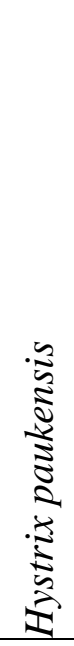 & 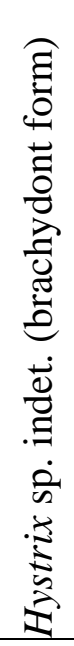 & 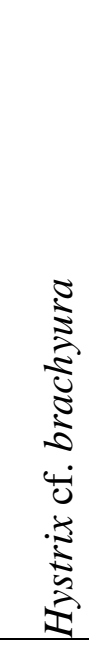 & 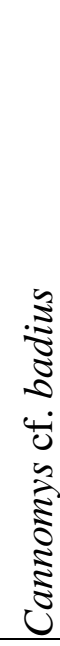 & 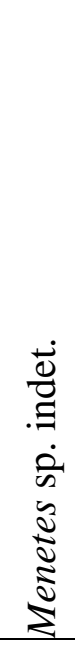 \\
\hline Holocene & $\bigcirc$ & & & & & & $\bigcirc$ & 0 & \\
\hline L. Pleistocene & $\bigcirc$ & & & & & & $\bigcirc$ & & \\
\hline M. Pleistocene & $\bigcirc$ & & & & & & $\bigcirc$ & & \\
\hline E. Pleistocene & 0 & 0 & 00 & 0 & 0 & & 00 & 0 & 0 \\
\hline L. Pliocene & 0 & 0 & 00 & 0 & 0 & 0 & 00 & 0 & 0 \\
\hline L. Miocene/E. Pliocene & & & & & $\bigcirc$ & & & & \\
\hline
\end{tabular}


Appendix 1. List of the referred specimens in this study.

\begin{tabular}{|c|c|c|c|c|}
\hline No. & Family & Species & Material & Locality \\
\hline IR 1955 & Muridae & Hapalomys cf. longicaudatus & R. mandible $\left(\mathrm{I}_{1}, \mathrm{M}_{1}-\mathrm{M}_{3}\right)$ & $\mathrm{Mg} 1 / 2$ \\
\hline IR 1965 & Muridae & Hapalomys cf. longicaudatus & L. mandible $\left(\mathrm{M}_{2}-\mathrm{M}_{3}\right)$ & $\operatorname{Mg} 1 / 2$ \\
\hline IR 1966 & Muridae & Hapalomys cf. longicaudatus & L. maxilla $\left(\mathrm{M}^{1}\right)$ & $\operatorname{Mg} 1 / 2$ \\
\hline IR 1967 & Muridae & Hapalomys cf. longicaudatus & L. mandible $\left(\mathrm{M}_{2}\right)$ & $\operatorname{Mg} 1 / 2$ \\
\hline IR 2105 & Muridae & Hapalomys cf. longicaudatus & R. $\mathrm{M}_{2}$ & $\mathrm{Mg} 1 / 2$ \\
\hline IR 2523 & Muridae & Hapalomys cf. longicaudatus & L. mandible $\left(\mathrm{M}_{2}\right)$ & $\operatorname{Mg} 1 / 2$ \\
\hline IR 2524 & Muridae & Hapalomys cf. longicaudatus & R. mandible $\left(\mathrm{M}_{1}\right)$ & $\mathrm{Mg} 1 / 2$ \\
\hline IR 2541 & Muridae & Hapalomys cf. longicaudatus & L. $\mathrm{M}^{1}$ & $\mathrm{Mg} 1 / 2$ \\
\hline IR 2542 & Muridae & Hapalomys cf. longicaudatus & L. $\mathrm{M}^{1}$ & $\operatorname{Mg} 1 / 2$ \\
\hline IR 2543 & Muridae & Hapalomys cf. longicaudatus & R. $M^{1}$ & $\operatorname{Mg} 1 / 2$ \\
\hline IR 2544 & Muridae & Hapalomys cf. longicaudatus & L. $\mathrm{M}_{2}$ & $\mathrm{Mg} 1 / 2$ \\
\hline IR 2545 & Muridae & Hapalomys cf. longicaudatus & R. $\mathrm{M}_{2}$ & $\operatorname{Mg} 1 / 2$ \\
\hline IR 1995 & Muridae & Maxomys pliosurifer sp. nov. & R. maxilla $\left(\mathrm{M}^{1}-\mathrm{M}^{3}\right)$ & $\mathrm{Mg} 1 / 2$ \\
\hline IR 2057 & Muridae & Maxomys pliosurifer sp. nov. & R. mandible $\left(\mathrm{M}_{1}\right)$ & $\operatorname{Mg} 1 / 2$ \\
\hline IR 2067 & Muridae & Maxomys pliosurifer sp. nov. & L. mandible $\left(\mathrm{M}_{1}-\mathrm{M}_{3}\right)$ & $\operatorname{Mg} 1 / 2$ \\
\hline IR 2552 & Muridae & Maxomys pliosurifer sp. nov. & L. $M^{1}$ & $\operatorname{Mg} 1 / 2$ \\
\hline IR 2553 & Muridae & Maxomys pliosurifer sp. nov. & R. $\mathrm{M}^{2}$ & $\operatorname{Mg} 1 / 2$ \\
\hline IR 2554 & Muridae & Maxomys pliosurifer sp. nov. & L. $\mathrm{M}^{2}$ & $\operatorname{Mg} 1 / 2$ \\
\hline IR 2556 & Muridae & Maxomys pliosurifer sp. nov. & L. $\mathrm{M}_{1}$ & $\operatorname{Mg} 1 / 2$ \\
\hline IR 1929 & Muridae & Rattus jaegeri & L. mandible $\left(\mathrm{M}_{1}-\mathrm{M}_{3}\right)$ & $\operatorname{Mg} 1 / 2$ \\
\hline IR 2106 & Muridae & Rattus jaegeri & L. $M^{1}$ & $\operatorname{Mg} 1 / 2$ \\
\hline IR 2108 & Muridae & Rattus jaegeri & R. $M^{1}$ & $\operatorname{Mg} 1 / 2$ \\
\hline IR 2548 & Muridae & Rattus jaegeri & L. $\mathrm{M}^{1}$ & $\operatorname{Mg} 1 / 2$ \\
\hline IR 2555 & Muridae & Rattus jaegeri & R. $M^{2}$ & $\operatorname{Mg} 1 / 2$ \\
\hline IR 2832 & Muridae & Rattus jaegeri & L. $\mathrm{M}^{1}$ & $\mathrm{Mg} 1 / 2$ \\
\hline IR 1964 & Muridae & Cf. Rattus sp. indet. & L. mandible $\left(\mathrm{I}_{1}, \mathrm{M}_{1}-\mathrm{M}_{3}\right)$ & $\operatorname{Mg} 1 / 2$ \\
\hline IR 2056 & Muridae & Cf. Rattus sp. indet. & R. mandible $\left(\mathrm{M}_{2}-\mathrm{M}_{3}\right)$ & $\mathrm{Mg} 1 / 2$ \\
\hline IR 2104 & Muridae & Cf. Rattus sp. indet. & L. mandible $\left(\mathrm{M}_{2}-\mathrm{M}_{3}\right)$ & $\operatorname{Mg} 1 / 2$ \\
\hline IR 2551 & Muridae & Cf. Rattus sp. indet. & L. maxilla $\left(\mathrm{M}^{1}-\mathrm{M}^{3}\right)$ & $\mathrm{Mg} 1 / 2$ \\
\hline IR 2833 & Muridae & Cf. Rattus sp. indet. & L. $\mathrm{M}^{2}$ & $\operatorname{Mg} 1 / 2$ \\
\hline IR 2834 & Muridae & Cf. Rattus sp. indet. & R. $\mathrm{M}_{3}$ & $\operatorname{Mg} 1 / 2$ \\
\hline M1-178 & Muridae & Cf. Rattus sp. indet. & R. mandible $\left(\mathrm{I}_{1}, \mathrm{M}_{2}-\mathrm{M}_{3}\right)$ & Psw1 \\
\hline IR 1620 & Hystricidae & Hystrix paukensis & R. $\mathrm{M}_{3}$ & Gbn5 \\
\hline IR 1959 & Hystricidae & Hystrix paukensis & R. $\mathrm{M}_{3}$ & GbnF1 \\
\hline M1-108 & Hystricidae & Hystrix paukensis & L. $\mathrm{M}_{1 / 2}$ & TBG1 \\
\hline IR 1560 & Hystricidae & Hystrix sp. indet. (brachydont form) & L. $\mathrm{M}^{1 / 2}$ & TBG1 \\
\hline IR 1871 & Hystricidae & Hystrix sp. indet. (brachydont form) & L. $\mathrm{M}_{1 / 2}$ & $\operatorname{Mg} 1 / 2$ \\
\hline IR 1927 & Hystricidae & Hystrix sp. indet. (brachydont form) & L. $\mathrm{P}_{4}$ & $\operatorname{Mg} 1 / 2$ \\
\hline IR 1957 & Hystricidae & Hystrix sp. indet. (brachydont form) & R. $\mathrm{M}^{1 / 2}$ & $\operatorname{Mg} 1 / 2$ \\
\hline IR 1958 & Hystricidae & Hystrix sp. indet. (brachydont form) & R. $\mathrm{dP}_{4}$ & Gbn5 \\
\hline IR 2058 & Hystricidae & Hystrix sp. indet. (brachydont form) & L. $\mathrm{P}^{4}$ & $\operatorname{Mg} 1 / 2$ \\
\hline IR 2520 & Hystricidae & Hystrix sp. indet. (brachydont form) & L. $\mathrm{M}_{1 / 2}$ & $\operatorname{Mg} 1 / 2$ \\
\hline IR 2521 & Hystricidae & Hystrix sp. indet. (brachydont form) & L. $\mathrm{M}_{3}$ & $\operatorname{Mg} 1 / 2$ \\
\hline M1-179-1 & Hystricidae & Hystrix sp. indet. (brachydont form) & R. $M_{1 / 2}$ & $\operatorname{Mg} 1 / 2$ \\
\hline M1-179-2 & Hystricidae & Hystrix cf. brachyura & R. $M_{1 / 2}$ & $\operatorname{Mg} 1 / 2$ \\
\hline IR 1956 & Spalacidae & Cannomys cf. badius & R. $\mathrm{M}_{1}$ & $\operatorname{Mg} 1 / 2$ \\
\hline IR 2102 & Spalacidae & Cannomys cf. badius & L. $\mathrm{M}_{3}$ & $\operatorname{Mg} 1 / 2$ \\
\hline IR 2103 & Spalacidae & Cannomys cf. badius & R. $\mathrm{M}_{3}$ & $\mathrm{Mg} 1 / 2$ \\
\hline IR 2522 & Spalacidae & Cannomys cf. badius & R. $\mathrm{M}^{3}$ & $\mathrm{Mg} 1 / 2$ \\
\hline IR 2530 & Spalacidae & Cannomys cf. badius & R. $\mathrm{M}_{3}$ & $\operatorname{Mg} 1 / 2$ \\
\hline IR 2531 & Spalacidae & Cannomys cf. badius & L. $\mathrm{M}^{1}$ (broken) & $\operatorname{Mg} 1 / 2$ \\
\hline IR 2535 & Spalacidae & Cannomys cf. badius & R. $\mathrm{M}_{2}$ & $\operatorname{Mg} 1 / 2$ \\
\hline IR 2536 & Spalacidae & Cannomys cf. badius & R. $\mathrm{M}_{2}$ & $\mathrm{Mg} 1 / 2$ \\
\hline
\end{tabular}




\begin{tabular}{lllll}
\hline No. & Family & Species & Material & Locality \\
\hline IR 2537 & Spalacidae & Cannomys cf. badius & L. $\mathrm{M}^{2}$ & $\mathrm{Mg} 1 / 2$ \\
IR 2532 & Sciuridae & Menetes sp. indet. & L. $\mathrm{P}_{4}$ & $\mathrm{Mg} 1 / 2$ \\
IR 2533 & Sciuridae & Menetes sp. indet. & L. $\mathrm{M}_{2}$ & $\mathrm{Mg} 1 / 2$ \\
IR 2534 & Sciuridae & Menetes sp. indet. & $\mathrm{R} . \mathrm{M}_{3}$ & $\mathrm{Mg} 1 / 2$ \\
IR 2835 & Sciuridae & Menetes sp. indet. & L. $\mathrm{P}_{4}$ & $\mathrm{Mg} 1 / 2$ \\
IR 2836 & Sciuridae & Menetes sp. indet. & L. $\mathrm{M}_{1}$ & $\mathrm{Mg} 1 / 2$ \\
IR 2837 & Sciuridae & Menetes sp. indet. & L. $\mathrm{M}_{2}$ & $\mathrm{Mg} 1 / 2$ \\
IR 2838 & Sciuridae & Menetes sp. indet. & & $\mathrm{Mg} 1 / 2$ \\
\hline
\end{tabular}


Appendix 2. Measurements in mm of Muridae fossils from Gwebin area.

\begin{tabular}{|c|c|c|c|c|c|c|c|}
\hline & \multirow[t]{2}{*}{$\mathrm{M}^{1}-\mathrm{M}^{3}$} & \multicolumn{2}{|c|}{$\mathrm{M}^{1}$} & \multicolumn{2}{|c|}{$\mathrm{M}^{2}$} & \multicolumn{2}{|c|}{$\mathrm{M}^{3}$} \\
\hline & & $\mathrm{L}$ & $\mathrm{W}$ & $\mathrm{L}$ & $\overline{\mathrm{W}}$ & $\mathrm{L}$ & $\mathrm{W}$ \\
\hline \multicolumn{8}{|c|}{ Hapalomys cf. longicaudatus } \\
\hline IR 1966 & - & 4.09 & 2.78 & - & - & - & - \\
\hline IR 2541 & - & - & 2.64 & - & 一 & - & - \\
\hline IR 2542 & - & 4.11 & 2.81 & - & - & - & - \\
\hline IR 2543 & - & 4.10 & 2.76 & - & - & 一 & - \\
\hline \multicolumn{8}{|c|}{ Maxomys pliosurifer sp. nov. } \\
\hline IR 1995 & 7.18 & 3.17 & $2.11 *$ & 2.18 & 2.13 & 1.83 & 1.67 \\
\hline IR 2552 & - & 3.24 & 2.14 & - & - & - & - \\
\hline IR 2553 & - & - & - & 2.48 & 2.30 & - & - \\
\hline IR 2554 & - & 一 & - & 2.50 & 2.33 & 一 & - \\
\hline \multicolumn{8}{|c|}{ Rattus jaegeri } \\
\hline IR 2106 & - & 3.17 & 1.93 & - & - & 一 & - \\
\hline IR 2108 & - & 2.86 & 1.79 & - & 一 & 一 & - \\
\hline IR 2548 & - & 3.10 & 1.90 & - & - & - & - \\
\hline IR 2832 & - & - & 2.01 & - & - & 一 & - \\
\hline IR 2555 & - & 一 & - & 2.12 & 1.94 & 一 & - \\
\hline \multicolumn{8}{|c|}{ Cf. Rattus sp. indet. } \\
\hline IR 2551 & 5.29 & 2.50 & 1.63 & 1.85 & 1.72 & 1.49 & 1.39 \\
\hline IR 2833 & - & - & - & 1.85 & 1.82 & 一 & - \\
\hline \multicolumn{8}{|c|}{ * alveolar size } \\
\hline & \multirow[t]{2}{*}{$\mathrm{M}_{1}-\mathrm{M}_{3}$} & \multicolumn{2}{|c|}{$\mathrm{M}_{1}$} & \multicolumn{2}{|c|}{$\mathrm{M}_{2}$} & \multicolumn{2}{|c|}{$\mathrm{M}_{3}$} \\
\hline & & $\mathrm{L}$ & $\mathrm{W}$ & $\mathrm{L}$ & $\mathrm{W}$ & $\mathrm{L}$ & $\mathrm{W}$ \\
\hline \multicolumn{8}{|c|}{ Hapalomys cf. longicaudatus } \\
\hline IR 1955 & 8.19 & 3.67 & 2.32 & 2.47 & 2.34 & 2.30 & 2.03 \\
\hline IR 2524 & - & $3.71 *$ & 2.51 & - & - & - & - \\
\hline IR 1965 & - & - & - & 2.87 & 2.59 & 2.40 & 2.05 \\
\hline IR 1967 & - & $3.80 *$ & $2.27 *$ & 2.88 & 2.55 & $2.18 *$ & $2.09 *$ \\
\hline IR 2105 & - & - & - & 2.90 & 2.49 & - & - \\
\hline IR 2523 & - & $3.59 *$ & $2.19 *$ & 2.71 & 2.38 & - & - \\
\hline IR 2544 & - & - & - & 2.77 & 2.57 & 一 & - \\
\hline IR 2545 & - & - & - & 2.59 & 2.28 & - & - \\
\hline \multicolumn{8}{|c|}{ Maxomys pliosurifer sp. nov. } \\
\hline IR 2067 & 6.68 & 2.78 & 1.83 & 2.25 & 2.06 & 1.79 & 1.68 \\
\hline IR 2057 & - & 2.72 & 1.62 & - & - & - & - \\
\hline IR 2556 & - & 2.67 & 1.73 & - & - & 一 & - \\
\hline \multicolumn{8}{|c|}{ Rattus jaegeri } \\
\hline IR 1929 & 7.03 & 2.85 & 1.96 & 2.13 & 2.11 & 2.00 & 1.83 \\
\hline \multicolumn{8}{|c|}{ Cf. Rattus sp. indet. } \\
\hline IR 1964 & 5.19 & 2.00 & 1.40 & 1.73 & 1.55 & 1.66 & 1.43 \\
\hline IR 2056 & - & - & - & 1.61 & 1.58 & 1.61 & 1.43 \\
\hline IR 2104 & - & - & - & 1.64 & 1.62 & 1.53 & 1.48 \\
\hline M1-178 & - & - & - & 1.58 & 1.46 & 1.36 & 1.37 \\
\hline IR 2834 & - & - & - & - & - & 1.60 & 1.50 \\
\hline
\end{tabular}


Appendix 3. Measurements in mm of Hystrix fossils from Gwebin area, with referring $H$. paukensis from Chaingzauk area (IR 0822 and AML-N-IR 0036) and $H$. brachyura from Java (SMF/PA/F 5874 and 5875). H, maximum crown height measured on the lingual side of upper cheek teeth and the labial side of lower cheek teeth.

\begin{tabular}{|c|c|c|c|c|c|c|c|c|c|}
\hline & \multicolumn{3}{|c|}{$\mathrm{P}^{4}$} & \multicolumn{3}{|c|}{$\mathrm{M}^{1 / 2}$} & \multicolumn{3}{|c|}{$\mathrm{dP}_{4}$} \\
\hline & $\mathrm{L}$ & $\mathrm{W}$ & $\mathrm{H} / \mathrm{L}$ & $\mathrm{L}$ & $\mathrm{W}$ & $\mathrm{H} / \mathrm{L}$ & $\mathrm{L}$ & $\mathrm{W}$ & $\mathrm{H} / \mathrm{L}$ \\
\hline \multicolumn{10}{|c|}{$\overline{H . \text { sp. indet. (brachydont form) }}$} \\
\hline IR 2058 & 7.49 & 6.22 & 1.33 & - & - & - & 一 & 一 & - \\
\hline IR 1560 & - & - & - & 7.19 & 6.53 & 1.18 & 一 & - & - \\
\hline IR 1957 & - & - & - & 6.68 & 6.32 & 1.18 & - & - & - \\
\hline IR 1958 & - & - & - & - & - & - & 6.60 & 4.26 & - \\
\hline \multicolumn{10}{|c|}{ H. brachyura (fossil from Java) } \\
\hline \multirow[t]{3}{*}{$\mathrm{SMF} / \mathrm{PA} / \mathrm{F} 5874$} & 7.29 & 6.85 & 1.39 & 6.46 & 6.76 & 1.61 & 一 & 一 & - \\
\hline & \multicolumn{3}{|c|}{$\mathrm{P}_{4}$} & \multicolumn{3}{|c|}{$\mathrm{M}_{1 / 2}$} & \multicolumn{3}{|c|}{$\mathrm{M}_{3}$} \\
\hline & $\mathrm{L}$ & $\mathrm{W}$ & $\mathrm{H} / \mathrm{L}$ & $\mathrm{L}$ & $\mathrm{W}$ & $\mathrm{H} / \mathrm{L}$ & $\mathrm{L}$ & $\mathrm{W}$ & $\mathrm{H} / \mathrm{L}$ \\
\hline \multicolumn{10}{|l|}{$\overline{H . p a u k e n s i s}$} \\
\hline IR 0822 & 15.06 & 12.78 & 0.88 & $11.97 *$ & $12.86^{*}$ & - & $11.13^{*}$ & $12.26^{*}$ & - \\
\hline AML-N-IR 0036 & - & - & - & 13.25 & 10.94 & 0.72 & 12.50 & 10.04 & 0.72 \\
\hline M1-108 & - & - & - & 13.42 & 11.63 & 0.83 & - & - & - \\
\hline IR 1620 & - & - & 一 & 一 & - & 一 & 13.11 & 10.34 & 0.91 \\
\hline IR 1959 & - & - & - & 一 & 一 & 一 & 12.27 & 9.87 & 0.86 \\
\hline \multicolumn{10}{|c|}{ H. sp. indet. (brachydont form) } \\
\hline IR 1927 & 8.24 & 6.80 & 0.73 & - & - & - & - & - & - \\
\hline IR 1871 & - & - & - & 7.43 & 6.29 & 0.86 & - & - & - \\
\hline IR 2520 & - & - & - & 7.29 & 6.56 & 0.74 & - & - & - \\
\hline M1-179-1 & - & - & - & 6.90 & 6.36 & 1.14 & - & - & - \\
\hline IR 2521 & - & - & - & - & - & - & 6.40 & 5.43 & 0.60 \\
\hline \multicolumn{10}{|l|}{ H. cf. brachyura } \\
\hline M1-179-2 & - & - & - & 6.35 & 4.64 & 1.80 & - & - & - \\
\hline \multicolumn{10}{|c|}{ H. brachyura (fossil from Java) } \\
\hline SMF/PA/F 5875 & 7.42 & 6.13 & 1.85 & 7.69 & 6.56 & 1.37 & 6.26 & 5.17 & 1.62 \\
\hline
\end{tabular}

* alveolar size 
Appendix 4. Measurements in mm of Cannomys badius between Gwebin and extant species.

\begin{tabular}{|c|c|c|c|c|c|c|}
\hline & \multicolumn{2}{|c|}{$\mathrm{M}^{1}$} & \multicolumn{2}{|c|}{$\mathrm{M}^{2}$} & \multicolumn{2}{|c|}{$\mathrm{M}^{3}$} \\
\hline & $\mathrm{L}$ & $\mathrm{W}$ & $\mathrm{L}$ & $\mathrm{W}$ & $\mathrm{L}$ & $\mathrm{W}$ \\
\hline \multicolumn{7}{|l|}{$\overline{C . \text { cf. badius }}$} \\
\hline IR 2531 & - & 4.17 & - & - & - & - \\
\hline IR 2537 & - & - & 2.88 & 3.42 & - & - \\
\hline IR 2522 & - & - & - & - & 2.50 & 2.66 \\
\hline \multicolumn{7}{|c|}{ C. badius (extant) } \\
\hline KUM no.95 & 3.64 & 3.16 & 2.63 & 3.22 & 2.15 & 3.10 \\
\hline KUM no.99 & 3.88 & 3.99 & 2.79 & 3.58 & 2.63 & 2.92 \\
\hline \multirow[t]{3}{*}{ BNHS 9066} & 3.77 & 3.76 & 3.19 & 3.40 & 2.59 & 2.88 \\
\hline & \multicolumn{2}{|c|}{$\mathrm{M}_{1}$} & \multicolumn{2}{|c|}{$\mathrm{M}_{2}$} & \multicolumn{2}{|c|}{$\mathrm{M}_{3}$} \\
\hline & $\mathrm{L}$ & $\mathrm{W}$ & $\mathrm{L}$ & $\mathrm{W}$ & $\mathrm{L}$ & $\mathrm{W}$ \\
\hline \multicolumn{7}{|l|}{ C.cf. badius } \\
\hline IR 1956 & 3.76 & 3.05 & - & - & - & - \\
\hline IR 2535 & - & - & 3.13 & 3.46 & - & - \\
\hline IR 2536 & - & - & 3.18 & 3.67 & - & - \\
\hline IR 2102 & - & - & - & - & 3.87 & 3.67 \\
\hline IR 2103 & - & - & - & - & - & 3.34 \\
\hline IR 2530 & - & - & - & - & 4.13 & 3.00 \\
\hline \multicolumn{7}{|c|}{ C. badius (extant) } \\
\hline KUM no.95 & 3.73 & 3.44 & 2.42 & 3.72 & 3.62 & 3.49 \\
\hline KUM no.99 & 3.92 & 3.24 & 2.77 & 3.98 & 3.19 & 3.52 \\
\hline BNHS 9066 & 4.34 & 3.36 & 2.85 & 3.64 & 3.26 & 3.23 \\
\hline
\end{tabular}


Appendix 5. Measurements in mm of Menetes sp. indet. from Gwebin area.

\begin{tabular}{ccc}
\hline & $\mathrm{L}$ & $\mathrm{W}$ \\
\hline Menetes sp. indet. & & \\
IR 2532 $\left(\mathrm{P}_{4}\right)$ & 2.16 & 1.75 \\
IR 2835 $\left(\mathrm{P}_{4}\right)$ & 1.89 & 1.41 \\
IR 2836 $\left(\mathrm{M}_{1}\right)$ & 2.04 & 2.33 \\
IR 2837 $\left(\mathrm{M}_{1}\right)$ & 2.04 & 2.27 \\
IR 2533 $\left(\mathrm{M}_{2}\right)$ & 2.49 & 2.38 \\
IR 2838 $\left(\mathrm{M}_{2}\right)$ & 2.26 & 2.11 \\
IR 2534 $\left(\mathrm{M}_{3}\right)$ & 2.59 & 2.15 \\
\hline
\end{tabular}

